\title{
أثر الإعلام فى الطفل وأدبه
}

\author{
د.عزة محمد رشاد على سرج \\ مدرس الإعلام التربوي بكلية التربية النوعية - جامعة بهها
}


ينتمي طفل القرن الحادي والعشرين وأدبـه إلى ما يُعَرف بعصر الإعلام حيث بلغت التقنية الحديثة والمعلومات في مجال الإعلام والاتصال غايات كبيرة في سعة الأفق وعمق الأثر وقوة التوجيه، وكلما كانت الرسالة الإعلامية أكثر قوة وانتنارا كانت المسئوليات والتبعات المترتبة عليها أكبر وأخطر ، وتتنحق الدراسة والتفكير •

وأصبحت وسائل الإعلام المرئية والمسموعة بأنماطها المختلفة شريكا فاعلا ومؤثرا في الطفل وأدبه، وبخاصة بعد أن أصبح أكثر تفاعلية وانفتاحا ووعيا بعالمه المعاصر • ومن أهم سمات هذه الوسائل: التتوع، والإثارة والتشويق، وسهولة التواصل، والتقاعلية- إيجابا أوسلبا- والتحرردن القيود حيث لم تترك مجالا إلا وقد طرقته، فضلا عن خصوصية الاطلاع والاستخدام لجمهور المتلقين صغارا أو كبارا. ومع اختلاف مستوى انضباط هذه الوسائل بالمبادئ الاجتماعية والمعايير القيمية وما تتركه من آثنار سلبية وإيجابية على جمهور الأطفال، تبدو الحاجة الماسة إلى التمبيز والانتقاء في البرامج التثقيفية والترويحية الموجهة للطفل حتى لا يتأثر بأية توجيهات سلبية أو أفكار هدامة. وإذا أدركنا أن الإعلام يُعد وسيلة مهمة فى تتمية مواهب الطفل، وتوسيع مداركه، وإطلاق خياله وتعميق هويته وثقافته، وأيضا يسهم بدور فاعل ومؤثر في تقويم لسانه وتشكيل عقله وتوجيه سلوكه وأدبه ولغته التي هي كيانه، فضلا عن تزويده بالمعلومات والمهارات والفنون التي تساعده على الإحاطة والتفوق، وهذا كله من أهداف أدب الطفل، ألزمنا ذلك بضرورة تنسيق العمل في كلا المجالين لتحقيق الترابط والخبرة المتكاملة من أجل النهوض بمستوى البرامج الإعلامية التي تتعكس إيجابيا على الطفل وأدبه. ولا ننسى في ذلك كله أهمية كتابة المادة الإعلامية ودورها في تعميق التواصل مـع الطفل، فالكاتب المبدع هو الذي يعيد انفعالاته حتى يستطيع الكتابة للطفل، ويتَّع وسائل تدفع إبداعه إلى التألق، منها: بساطة الفكرة ذات المغزى القِيَّسي والأخلاقي، واختيار العنـاوين المبتكرة القصيرة اللافتة والمثيرة، التي تعطي فكرة العمل المبدع، والمفردات المألوفة السهلة الخالية من التعقيد التي 
تثري قاموسـه اللغـوي وتترك أتثرا عميقـا في نفسه، والاسـتخدام المتـوع للأفهـال بـين الماضـي والحاضـر والمستقبل، والاهتمـام بالصور والرسوم والشكال الزخرفية،مع مراعاة حجم البنط الذي تكتب بـه الحروف وخصوصا في مرحلة الطفولة الأولى، كما يعتمد في الوصف على استخدام الحواس جميعها، ويهتم بالمقاطع القصيرة، والأحداث المتتابعة، وسرعة الحركة والإيقاع المتتاسق والمتتـاغم، والدخول في الموضـوع دون تمهيد على أن يوضـح الزمان والمكان والألقاب، وأيضـا يراعي المراحل العمرية التي يكتب لها، وأن لكل منها ثقافتها الخاصة، والانتباه إلى أن ثقافة الطفل وأدبه هما وجهان لعملة واحدة، باعتبارهما مسألتين متلازمتين بل إن الأدب جزء من هذه التقافة ،

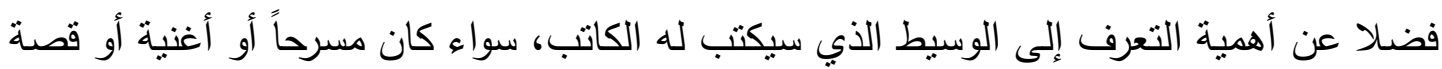
أو روايـة، أو أفـلام رسوم متحركة حيث أن هنـاك اختلافـا واضـحا بين تلك الأوسـاط، وضـرورة توظيف الخيال والحوار في القصة المكتوبة، مع إثراك الطفل في موضوعها بطربقة ما، لضمان تفاعله وتجاوبه معها، وعدم وضع حلول جاهزة، وإفساح المجال لخياله لإيجاد حلول مناسبة لها. وليس من شك في أن الأدب العربي جسد عبر عصوره المختلفة حقيقة هامة وهي أن الأدب وليد بيئته، يصور واقعها، ويعكس خصائصها، ويخاطب وجدان مجتمعها، بل كان في مرحلة ما يشكل فنه الرئيس، بوصفه ديوان الأمة، الحافظ لتاريخها، والثاهدد على قيمها ومُنّاها . وفي عصرنا الحديث طرأ عليه تطور وتطوير من حيث المضمون والشكل، ولعل في مقدمة هذا التطور أدب الطفل بوصف الطفل صانع الغد وعماد المسقبل. ومن ثم كان لابد أن يهيأ له كل الظروف التي تساعده على أن يكون ابن عصره، وأول ما يُقدّم له الأدب الذي يخاطب وجدانه وعقله، ويتتاسب مـع ظروف عصره التي اكتسبها من التكنولوجيا المحيطة بـه والتي غزت الحياة الإنسانية بجميع جوانبها، ممثلة في عـالم الكمبيوتر الرقمي والألعاب الإلكترونية التي باتت لا تفارقه، إضـافة إلى المحطات التلفزيونية المخصصة لله، لذلك يجب استخدام الصوت والصورة واللون في النوع الأدبي المكتوب للطفل، كمـا يجب أخذ إمكاناتـه الفكريـة والعلميـة في اعتبار الكاتب، والمساعدة العملية في نشر أفكاره وأعماله الأدبية والفنية. 
ومهما يكن من أمر ، فإن هناك ثورة لطفل جديد، باتت تظهر ملامحها على أطفال العالم، إذ إذ إنها

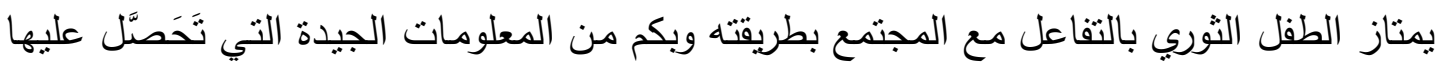

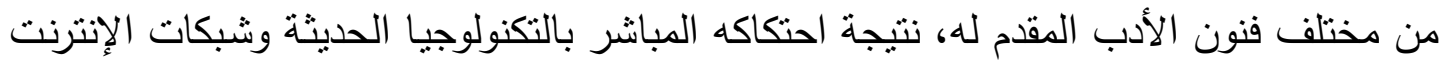

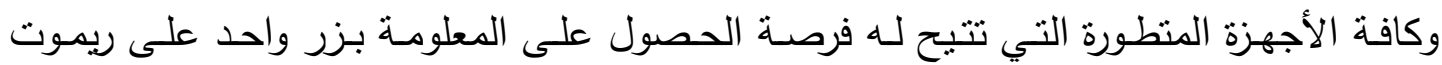
كونترول التلفزيون، أو لوحة مفاتيح الكمبيوتر ، أو جهاز الآي باد أو الآيفون.

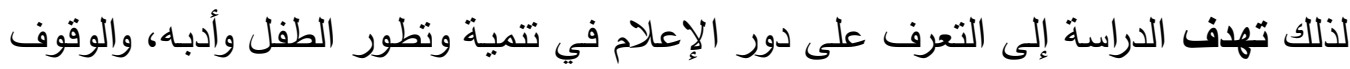

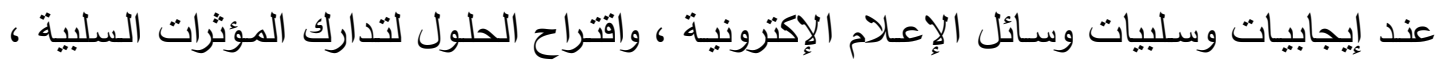

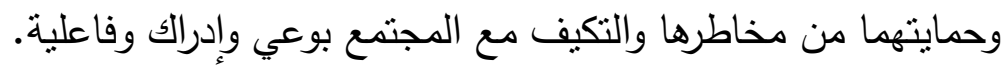

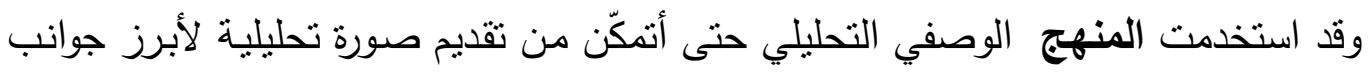

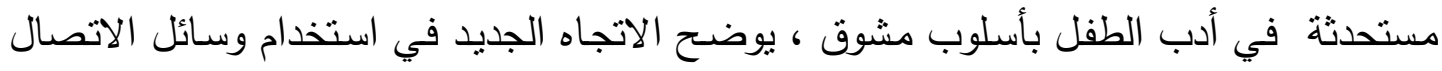

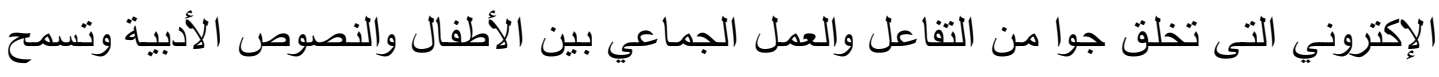

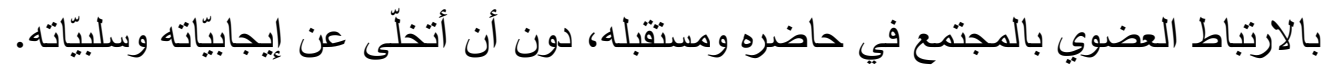

\section{تمبهـ:}

تُقاس حضارات الأمم على أساس مـا ثُقدِّهـه إلىى أطفالها مِن المعرفة الثقافية والاهتمام بأدب

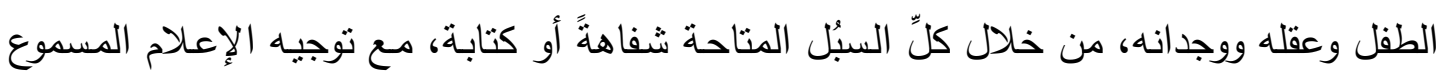

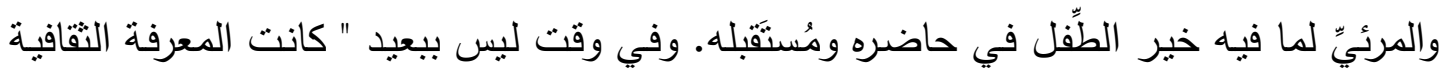

تقوم على قراءة النصوص الأدبية التقليدية عبر المطبوعات الثابتة والوسائط الورقية "((')

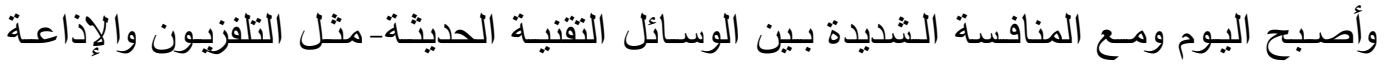

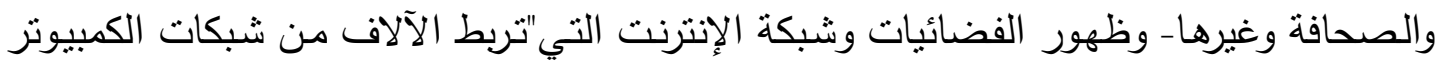

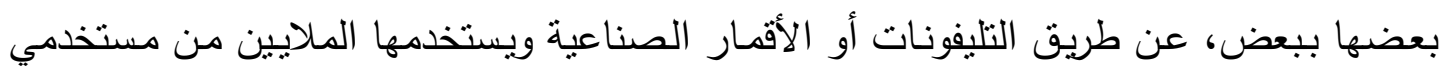

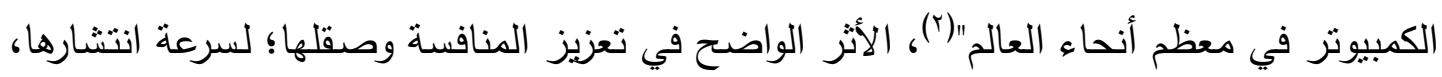


وسهولة الحصول على المعلومات والاطلاع على النصوص في عدة نسخ مختلفة ، فضلا عن قدرتها على تبادل المعلومات ، من خلال الحوار المباشر بين مختلف فئات المجتمع ، مما جعلها

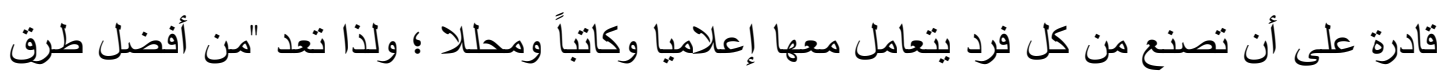

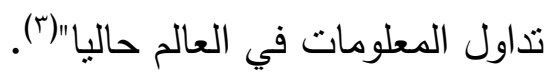

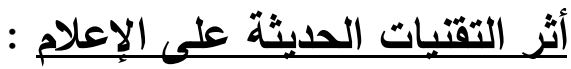

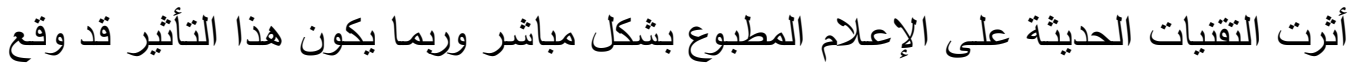
سلباً عليه، فمثلا استطاعت الفضائيات- عن غيرها من وسائل الإعلام الأخرى وبخاصة الصحافة الصاتة

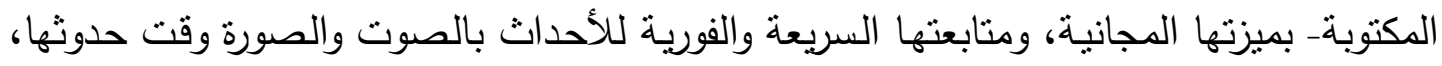

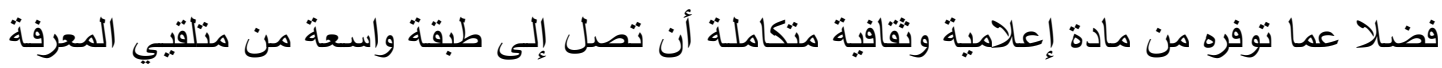

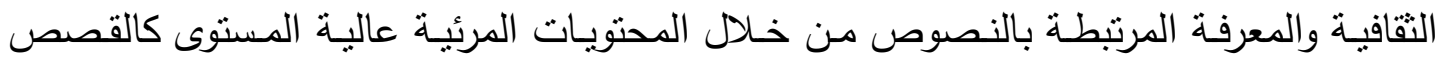

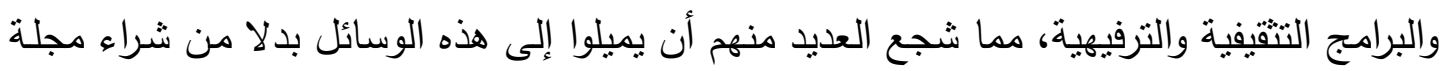

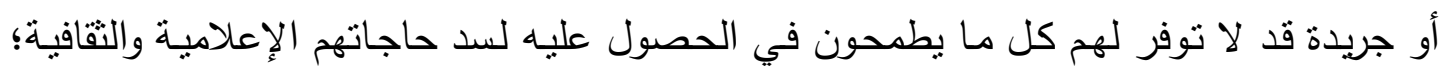

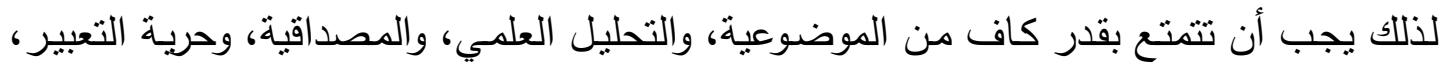
فضلا عن خدمة مصالح المجتمع صغارا وكباراً . ولما كانت حرية الإعلام من أهم مقومات المجتمع الحر، حيث تتقل وسائله كافة الأخبار

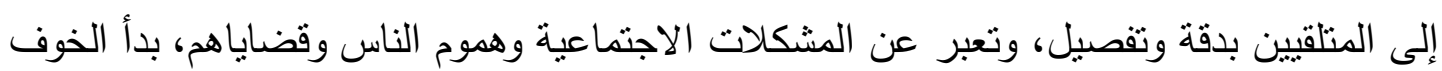

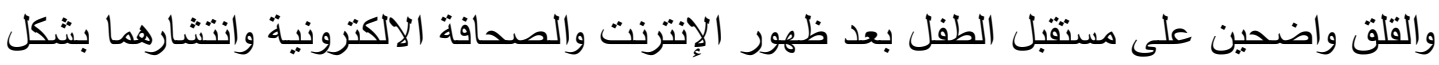
واسع وكثرة الإقبال عليهما من قبل مستخدمي الكمبيوتر • وهناك من يتوقع أن وسائل الإعلام المطبوعة والإصدارات الورقية بوجه عام سوف تفقد جانباً من أهميتها ودورها نتيجة لتلك التطورات

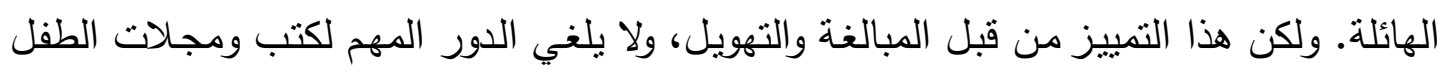

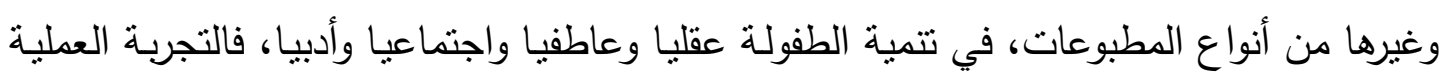


أثتبت أنه لا توجد وسيلة إعلامية تغني عن الأخرى، فما زالت كتب الطفل موجودة وقادرة على استقطاب جمهور القراء، والحقيقة تؤكد أن الإعلام المرئي والمكتوب سيظل لهما دور ووجود في الحياة ولن يستطيع أحدهما القضاء على الأخرى.

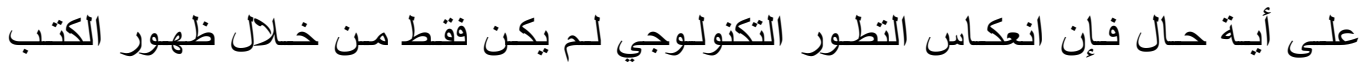
الإلكترونية، لكنه تجلى من خـلال الإعلام؛كونـه أهم وسائل الاتصـال المباشر ، وأدت التطورات

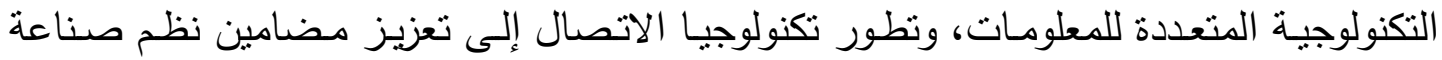

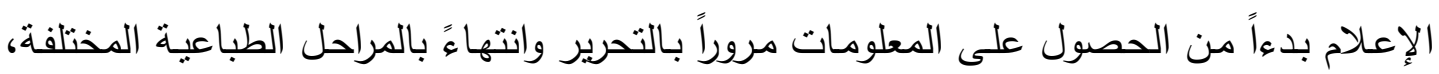

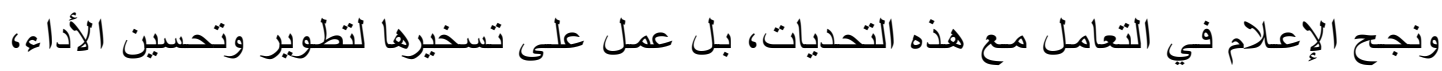

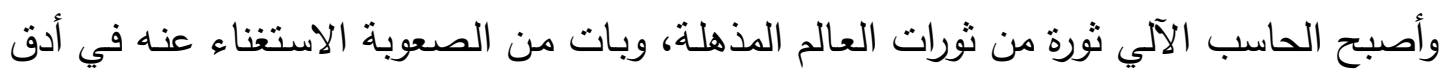

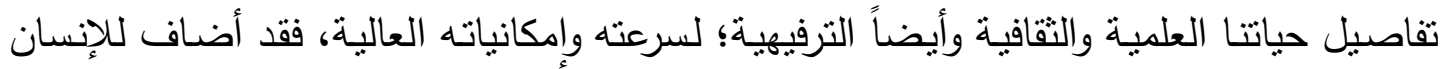
قدرات هائلة على الاحتفاظ بالمعلومات وانتقالها-بسرعة خيالية لم تكن تخطر على البال.

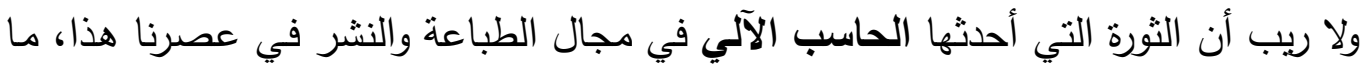

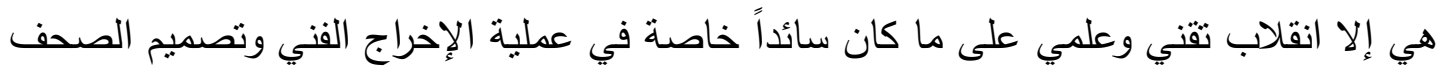

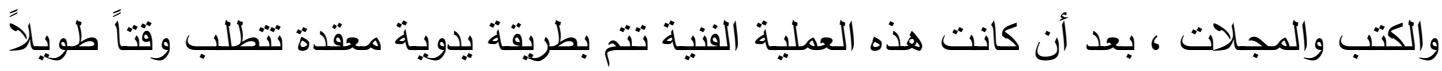

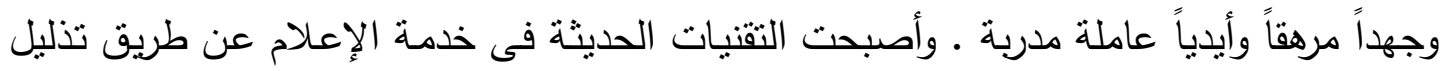

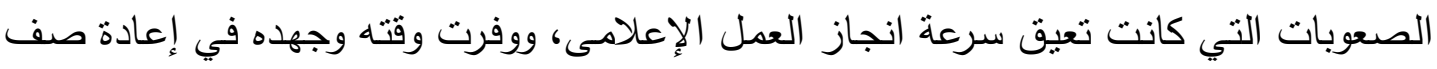

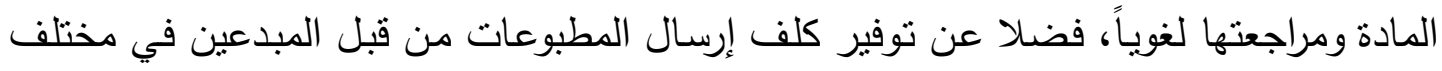

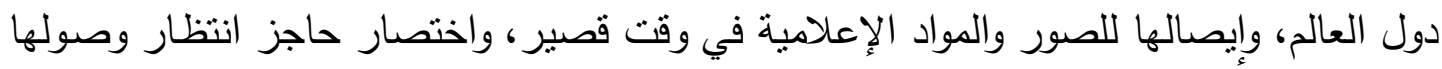
بالبريد العادي أو البريد السريع. وظهرت من خلال الحاسب الآلي الملتيميديا التي تعتمد على تقديم قصص وحكايات ومواقف التفريف

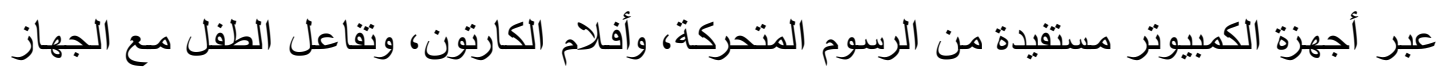

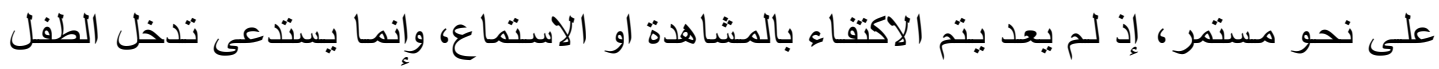


للكتابة أحياناً، ولوضع علامة أحياناً أخرى للالالة على تأكيد التعلم. وبذلك استطاعت أن تصل إلى التشويق والإثارة من خلال الدمج بين اللعب والترفيه والبناء القصصي، وتفاعلها مع الطفل

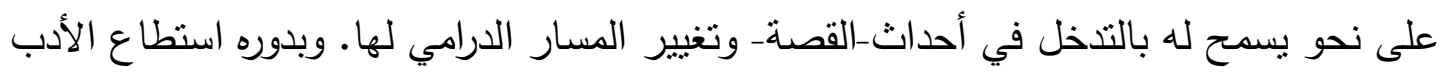
العالمي أن يقام للأطفال ألعاباً تجبرهم على التخطيط الاستراتيجي لاجتياز العقبات واتخاذ القرارات

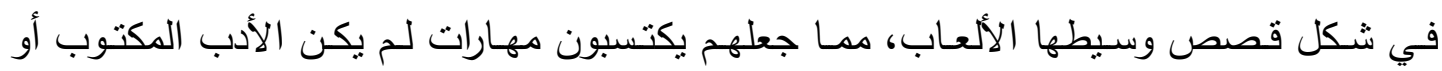

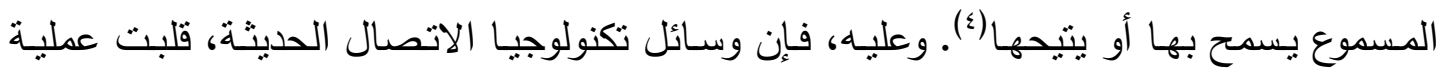
النتشئة والتثقيف رأسا على عقب، ومكّنت الطفل من أن يكون منتجا للثقافة، مبدعا للنصوص،

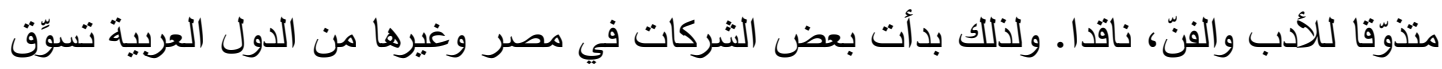
لإنتاجها الإلكتروني الجديد الذي يقدم على أسطوانات الليزر .

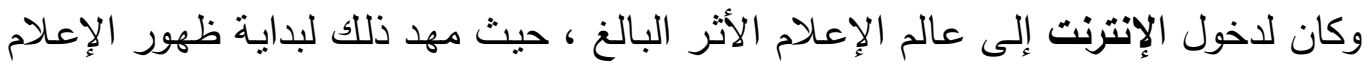

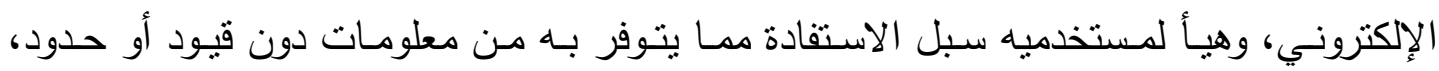

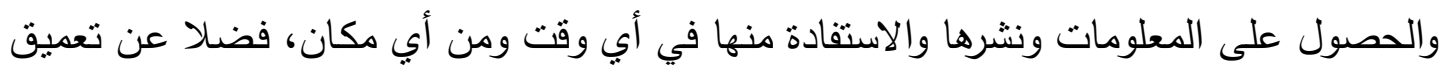

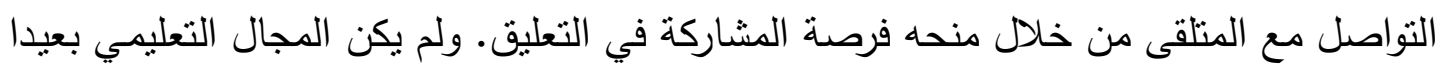

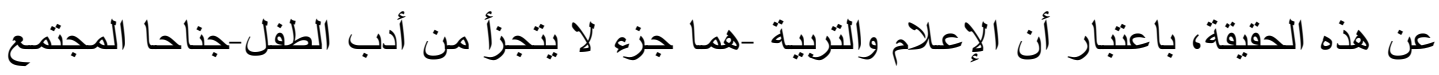

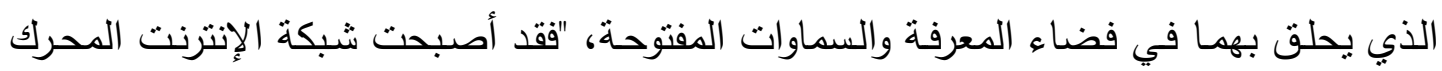

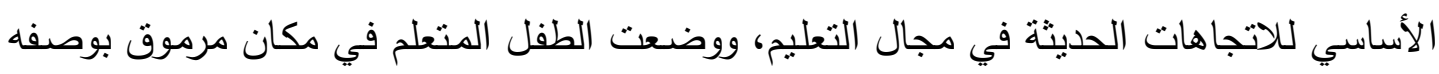

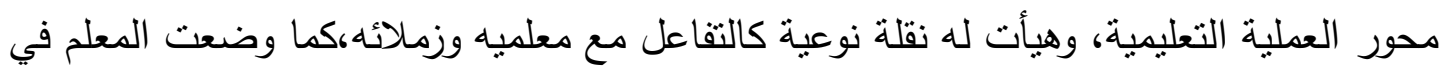

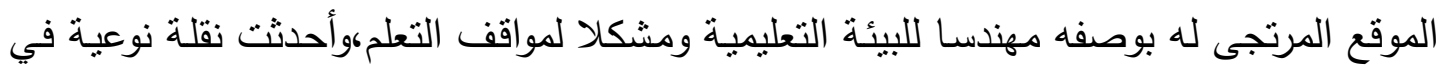
استراتيجيات التعليم والتعلم...وعالجت كثيرا من مشكلات المعلم والمتعلمكتضخم المعلومات وعجز

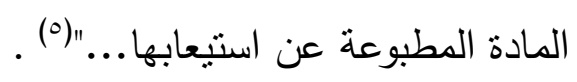

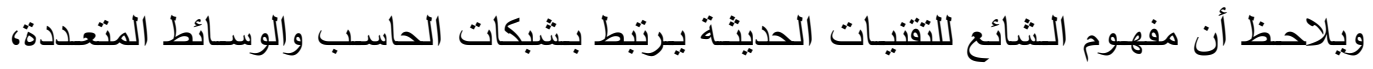

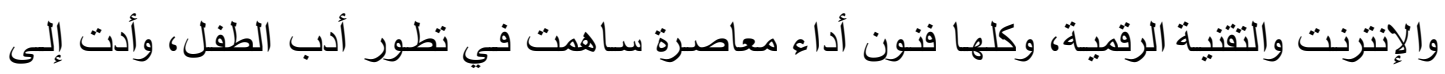


قصر المسافة بين الأطفال والتكنولوجيا حتى باتوا ينافسون الكبار في اقتتاء وشراء أجهزة الاتصال

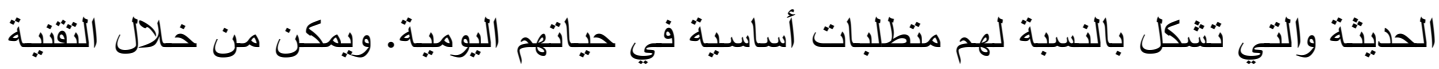

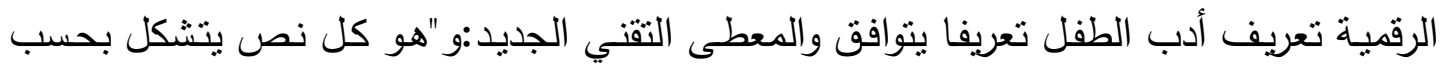

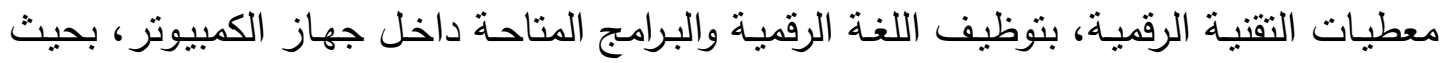

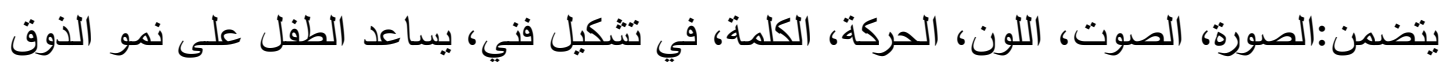

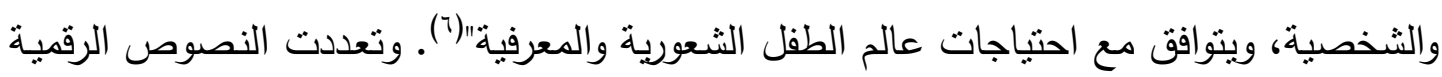

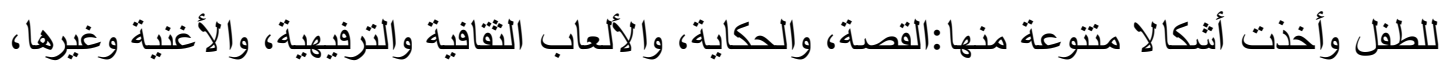

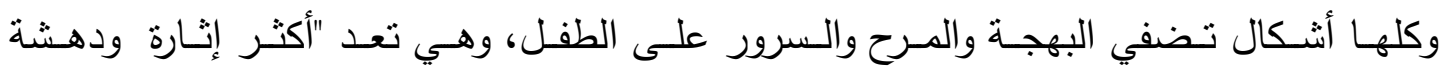

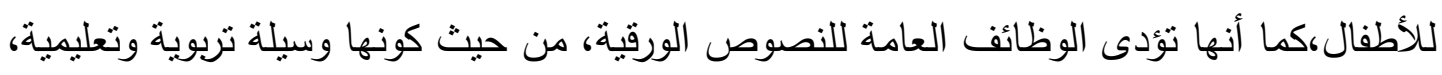

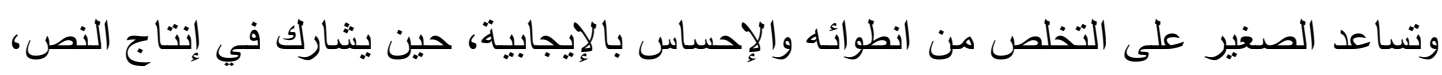

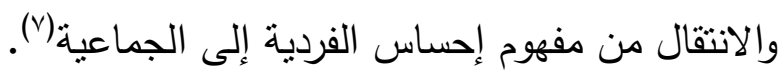

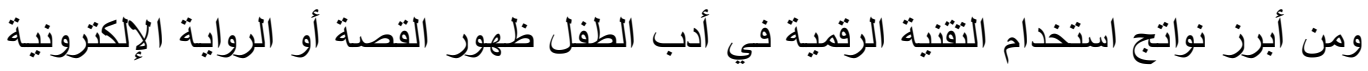

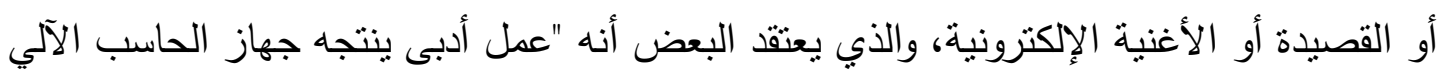

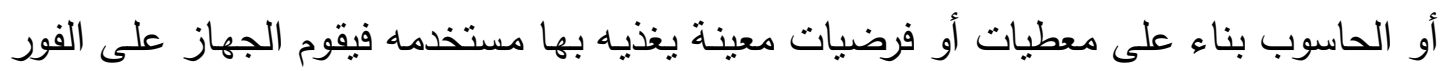

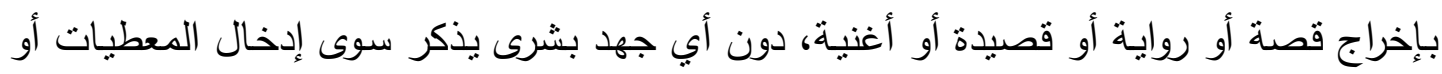

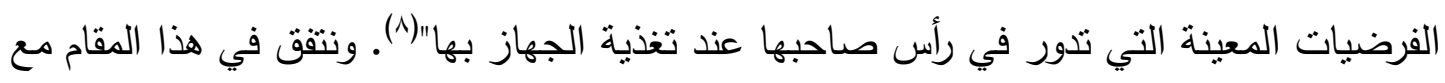

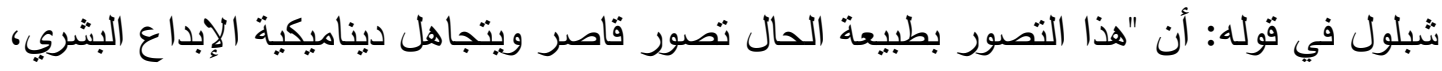

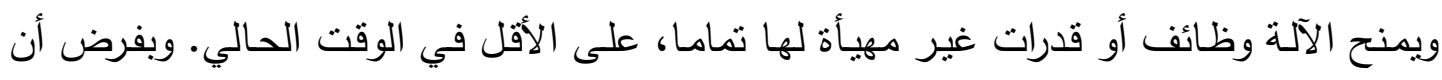

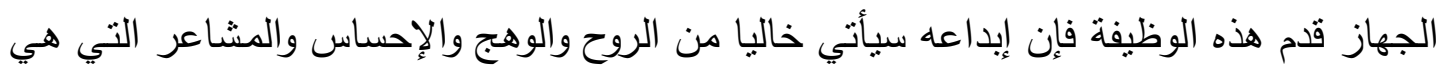
صفة التعامل والابداع البشرى"(9). ومصطلح القصة الإكترونيـة بعني عملية تصميم وتطوير قصة واقعية أو خيالية كانت مؤلفة من قَبْل تأليفا بشريا وتم تحويلها إلى الصيغة الإلكترونية وذلك باستخدام الأقراص الدمدجة 
CDRom مع إضافة بعض النقنيات الجديدة من صوت وصورة وحركة؛ لتحقيق غرض أو أخر . فعلى سبيل المثال حولت شركة صخر للحاسبات الآلية* قصة "القرد والغليم"^إحدى قصص كليلة

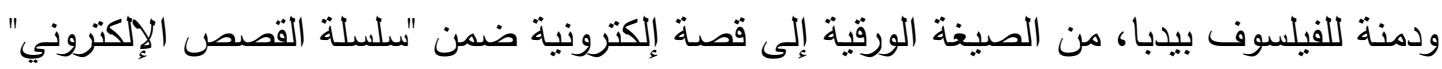

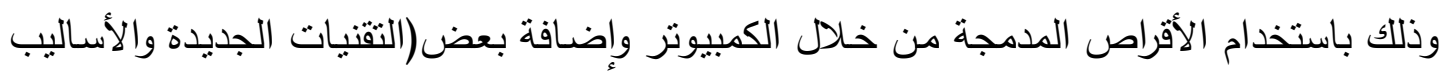

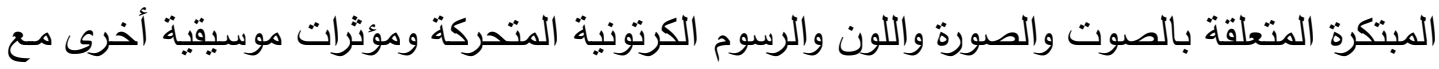

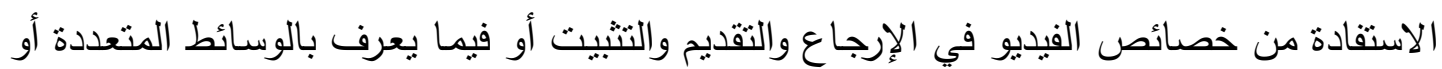
بالملتيميديا) (') (1)

ومازالت دور النشر الإلكتروني إلى وقتتا الحاضر تعتمد على كتب التراث فى تقديم مادتها

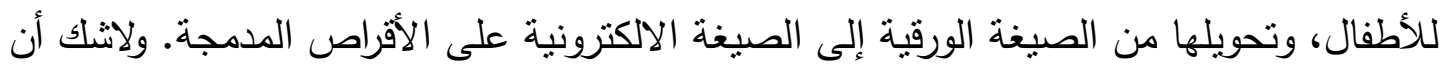

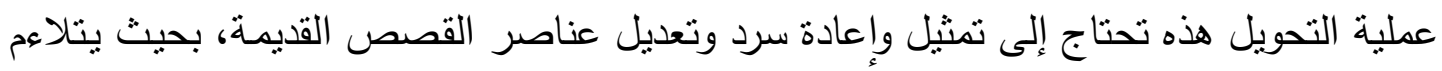

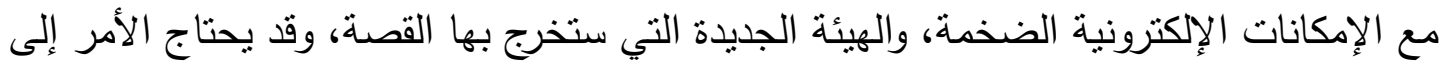

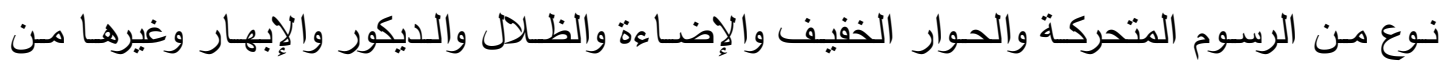

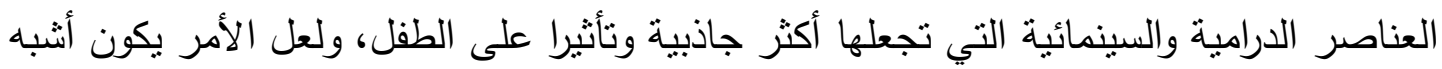

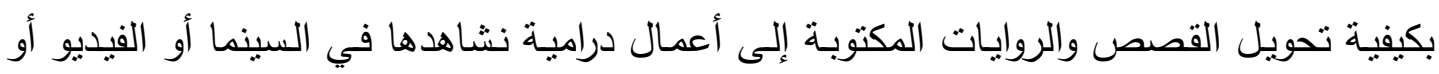

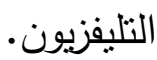
ولا شكك أن القصة الإكترونيـة بمـا تمتلكهـه من إمكانـات ضخمة تعد وسيلة من الوسـائل

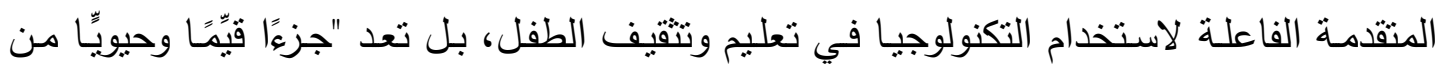

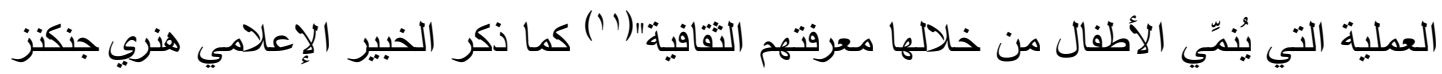

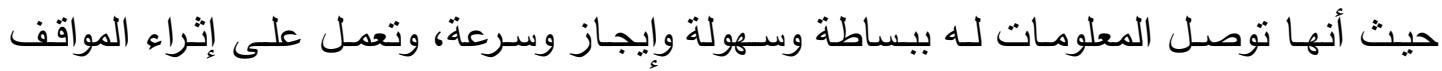

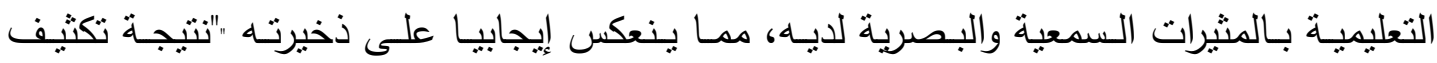

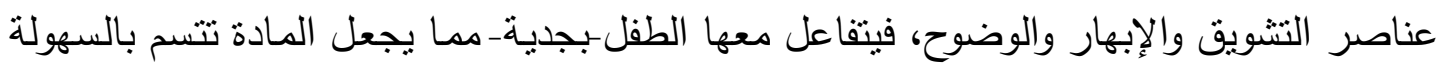
والبساطة"(r) (1). 
ولوحظ في السنوات الأخيرة وجود العديد من المؤسسات التعليمية الخاصة التي تهتم بتعليم الحاسب الآلي للأطفال وتدربهم على جميع ضروب وسائل الاتصال الحديثة مثل: الاتصالات الهاتقية والثبكات العالمية، الإنترنت، والتصوير الحى والحركة، وإدارة الكلمات ومعالجتها وغيرها من العمليات التي تضمن للطفل تطوير ملكة الإبداع الإكتروني فيه وتمنحه الثقة والاعتداد بنفسه. فثبكة المعلومات تعد عالما متشعبا بذاته يجب استغلالها والاستفادة من إمكاناتها وتطويرها

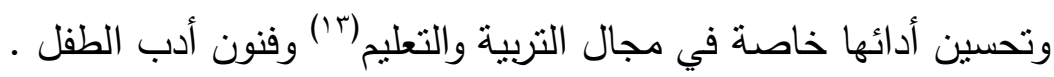

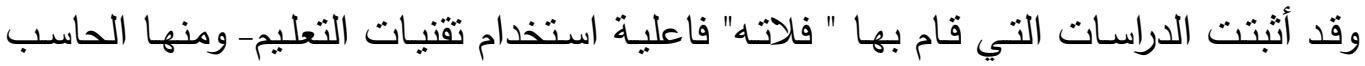
الآلي- في عملية التدريس حيث وفرت .0\% من وقت الحصة مع إمكانية الحصول على مستوى

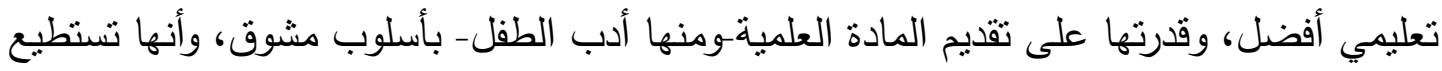

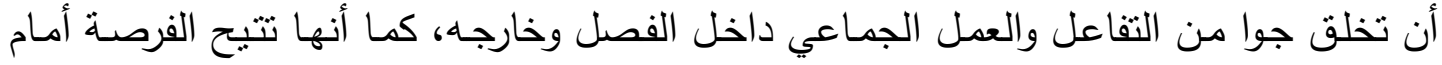

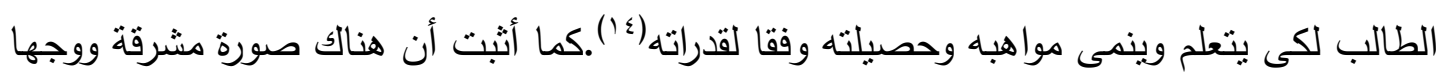
براقا لـ" تقنيات التعليم" ويتضح ذلك من خلال عنصر التنويق والإتارة والمتعة، والتحدي والفن في

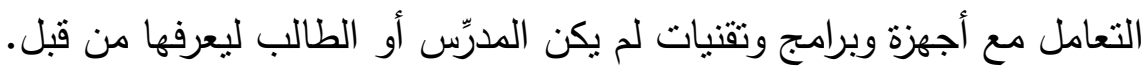

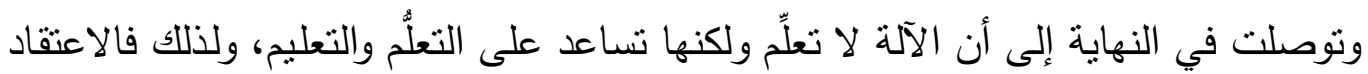

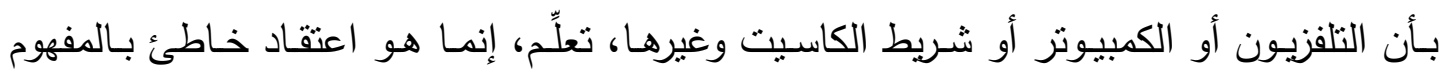

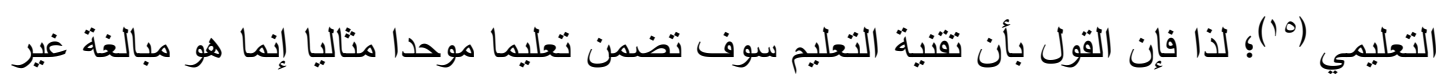

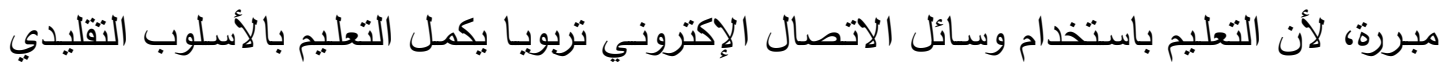

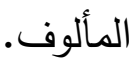

ومن الحكمة أن لا ننكر الدور الفاعل للحواسيب في المدارس، فقد قام كل من روجر شانك

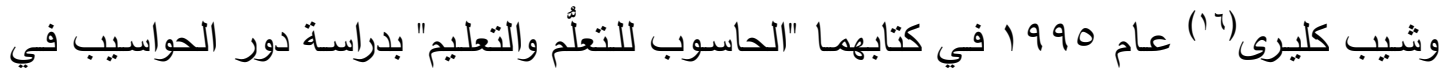

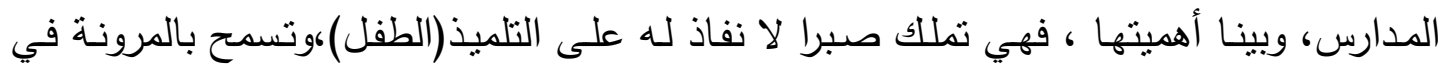

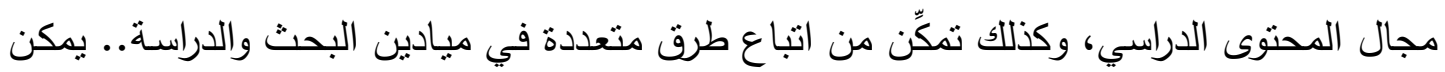


من خلالها فهم النصوص الأدبية عن طريق تمارين حول كلام متقطع ومختزل وتجرى كل هذه الأنشطة في جو من البهجة والسرور •

ولا شكَّ أن أدب الطفل من الوسـائل الثقافيـة والتربويـة الهامّة التي ينبغي توظيفهـا بفعاليـة

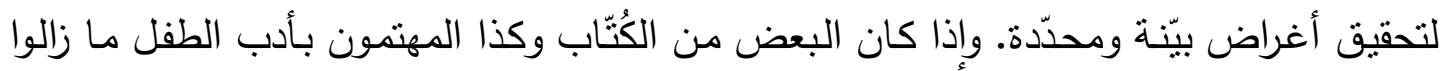
يعتقدون أن الكتابة للأطفال هينّة، سهُّة المنال. فإن هذا الاعنقاد خاطيٌٌ، فمن المتّقق عليه أدبيا

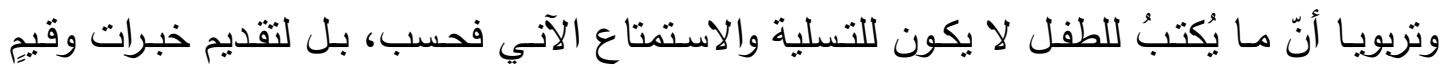

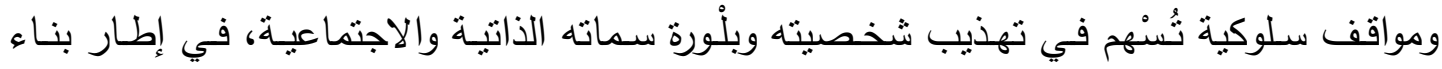

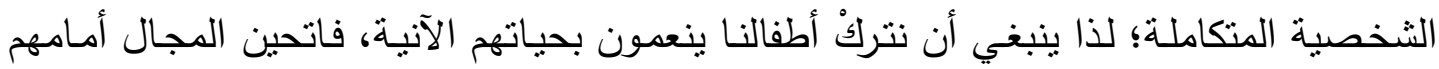
لاكتشاف المجاهيل دون خوْف عليهم من ناحية، ودون وصاية تتّسم بالتسلط من ناحية اخرى. نحن بحاجة إلى الوسائط التثقيفية العصرية التي تفتح آفاقا معرفية واسعة أمام أطفالنا وتسهر

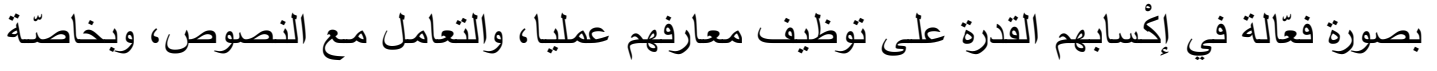

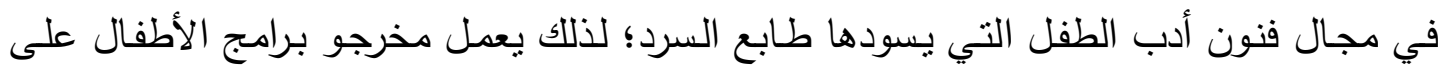

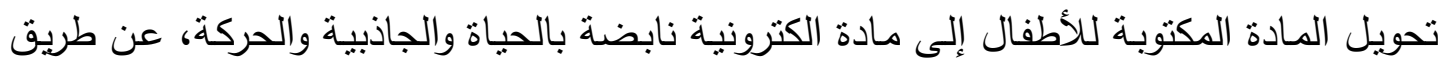
توزيع الوحدات المختلفة على الصفحة الإلكترونية الفارغة إلى لوحات فنية تنبض بالجمال والمعنى

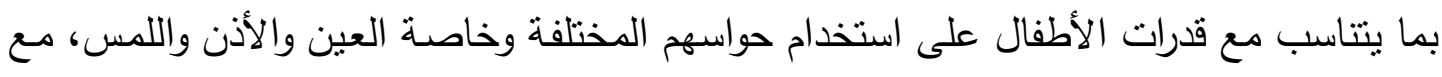

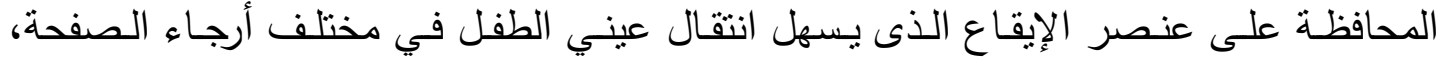

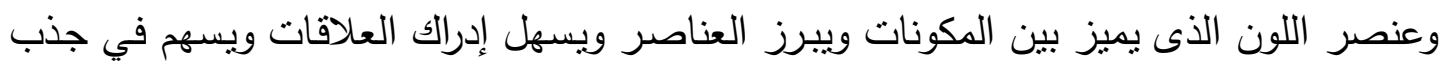
الانتباه والتشويق، فضلا عن استخدام المؤثرات البصرية والخدع السينمائية وتوزيع الاضاءة ومزج

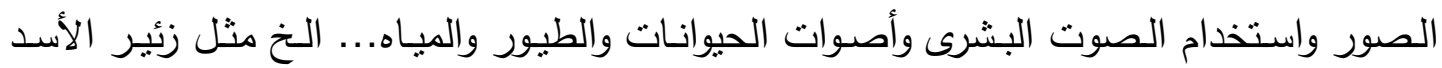

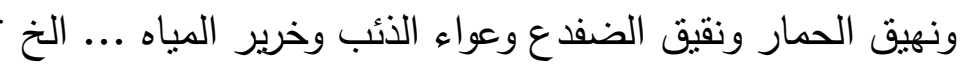




\section{إيجابيات وسائل الإعلام الإكترونية:}

مجـال اسـتخدام وسـائل الاتصـال الحديثـة في اتـساع متسارع ومعقّد، نتيجـة التطـورات التكنولوجية والثورة التي أحدثها الحاسب الآلى في مجالي الإعلام-كما أثرنا- وأدب الطفل، فقد وضـعت شـركات البرمجـة المحوسـبة بـين يـدي الطفل برمجيـات ذات ديناميكيـة سـريعة،متطوّرة التصاميم، جذابة وشيقة التعامل والتفعيل، متعددة الآليات، تمتاز بأنها ساعدت على تشجيع القراءة في أدب الطفل وتوسيع انتشار فنونه المختلفة. ومزجت بين مهارات اللعب وبين تسلسل أحداث القصة، وبذلك أصبحت الألعاب الإككترونية وسيلة فاعلة في تتمية التفكير المتوازي، حيث يواجه الطفل اللاعبُ عدّةَ مواقف، وعليه أن يتعامل معها في ذات الوقت. كما جعلته يتحكم بأحداثها، من خلال شق الطريق المحاط بالمخاطر والمفاجآت، وتركت دراماتيكية الأحداث وديناميكيتها رهن مهارة المستعمل لها. وكذلك أيضا ساهمت في تتمية التفكير المنطقي لديه ، حيث تعتمد البرمجة على تسلسل الخطوات، وتحليل المشكلة إلى عناصـرها الأولية. فضلا عن أنها طوّرت أسـاليب التخطيط الاستراتيجي لاجتياز العقبات وحسم المواقف، وبلورت النهج الفكري وساعدت على لمعان التفاصيل وإضاءة الطريق. وعلى هذا النحو وفرت التقنيات الحديثة وسـئل اتصال إلكترونية عديدة لتتمية المواهب الفنيـة لـدى الطفل في جميـع مجـالات الفنون الأدبيـة والنشكيلية والموسيقية. وأدى تعميم تقنيـة الإنترنت السريع، إلى تشجيع الكثثير من عثّاق الفكر والمعرفة على ولوج الثبكة العالميـة ، وأتاح فرصـة الإبحار عبر مواقع عديدة خاصـة بالطفولة، تزخر بنوافذ الثقافة العامـة مما شحْذ موهبـة الطفل المبدع، وشجعه على البحث والاكتشاف، ومواصلة التجريب، وإعادة المحاولة، والطفل في

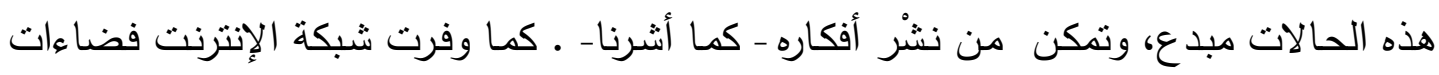
عالميـة رحبـة في عرض برامج الأطفال الترفيهيـة التقيفيـة، والاكتشاف والتواصل مـع الغير في مناطق مختلفة، والمساهمة في تتمية مهارات التواصل، فضلا عن توفير إمكانات عديدة لتجسيد المفاهيم المجرّدة، حتى يسهل استيعاب الطفل لها، ومجالات متتوعة من التعليم وتعلّم اللغة الأم 
واللغات الأجنيبة بوسائل عزض إلكترونية عديدة لقراءة الرسوم المتحركة، والقصص المصورة، وتتميـة الإبداع والتذوّق والأدبي • وهكذا سبب التقدم العلمي والتقنتي دخول وسـائل الاتصال

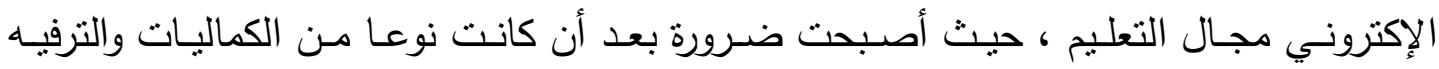

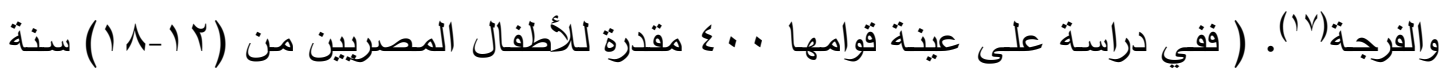
جاء الكبيوتر في مقدمة وسائل الاتصال الإكترونية التي يتعلم ويستفيد منها الطفل أثنياء جديدة

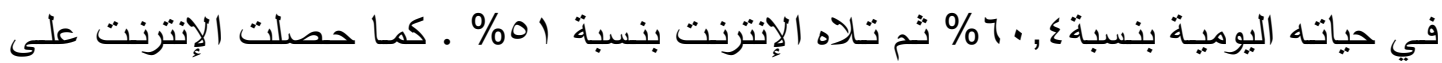

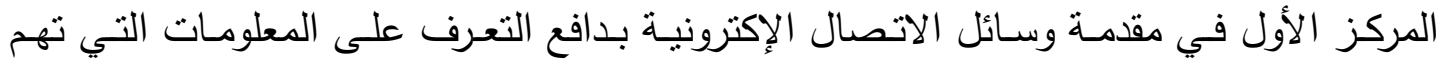

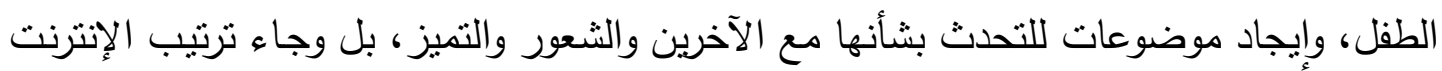

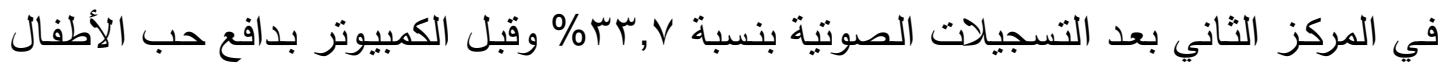

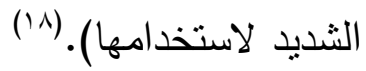

وعليه، فإن كل وسائل الاتصال الإكترونية خَطَت بفكر أطفال اليوم وساعدتهم على الارتقاء

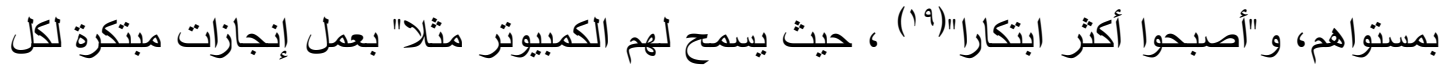

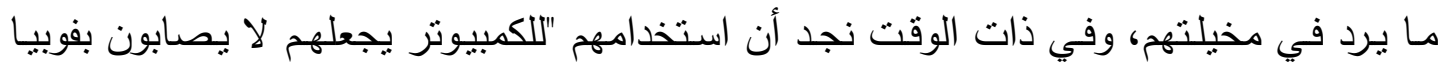

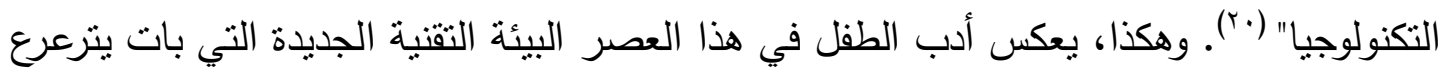
بين أحضانها طفل اليوم الذي يشكل المستقبل النقافي والحضاري والفكري لهجتمعنا.

\section{سليبات وسائل الإعلام الإكترونية:}

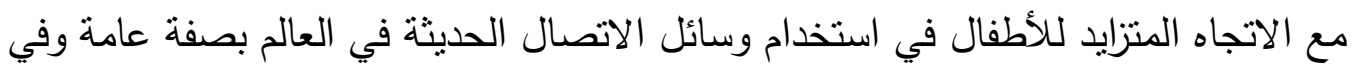

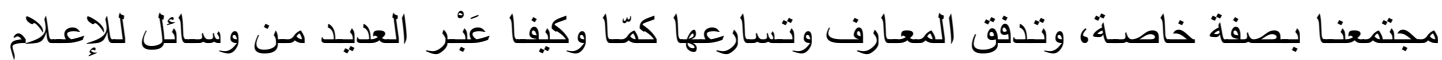

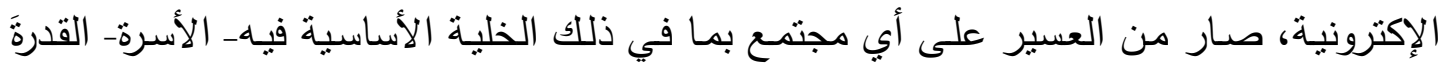

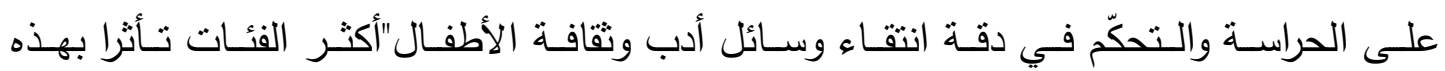
الفضائيات"(r). ولعل من أهم مظاهر الخطورة على الطفل المتعامل مع وسائل الاتصال الحديثة، 
أنه أصبح في عصرنا الحاضر عبدا لما تقدمه له مواقع الإنترنت والهواتف المحمولة من ألعاب التهاب

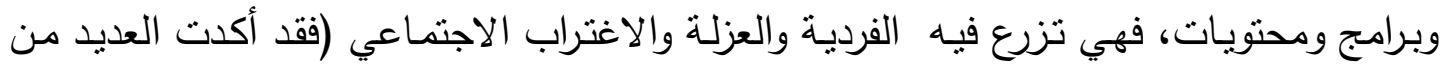

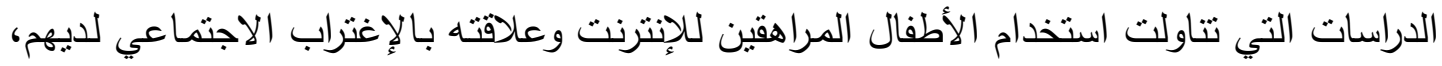

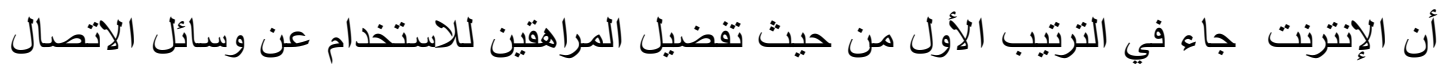

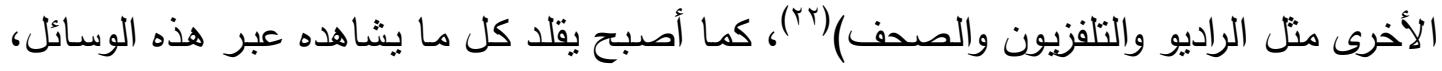

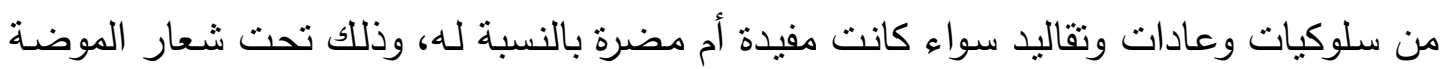
والانفتاح على الآخر ومواكبة نطورات العصر ، وما نثاهده اليوم في واقعنا من انحلال للأخلاق

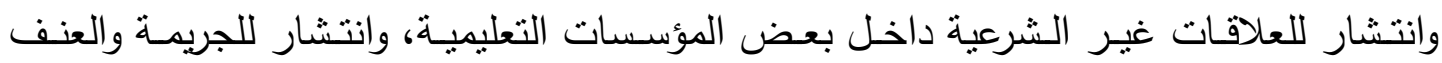
والاغتصاب والمخدرات، وتبادل الصور الإباحية بين الأطفال خير دليل على مخاطر وسلبيات

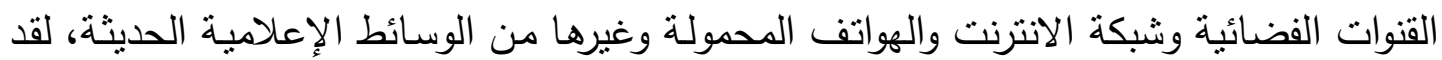
جعلت هذه الوسائط الطفل يعيش في عالم لا يدرك ماذا يفعل فيه حيث جعلته يعيش في عالم الماند خيالي بعيدا عن مجتمعه وأسرته، يفكر دوما في محاولة الوصول إلى هذا العالم المثالي الذي الذي

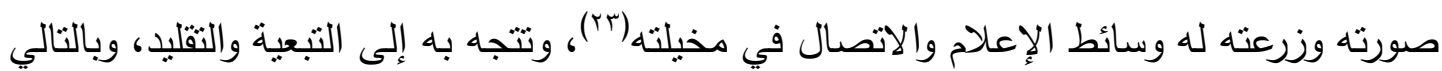

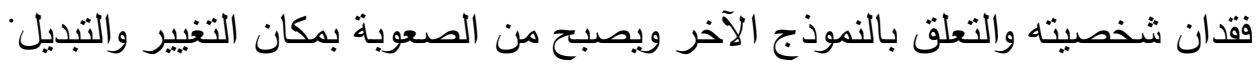

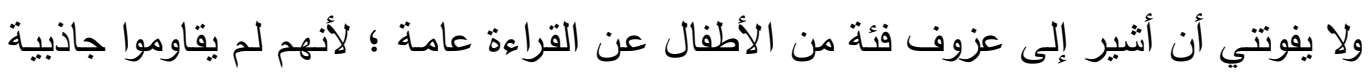

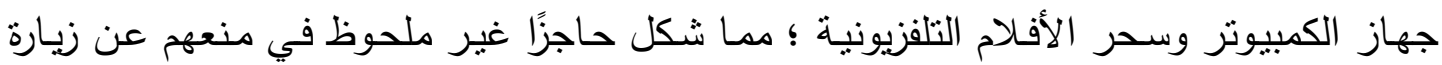

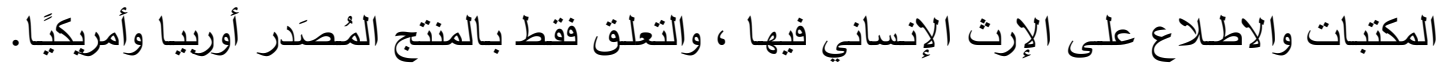
وكذلك خطورة الكتب المترجمة إلى العربية وتسويقها عبر الإنترنت، وهي ظاهرة جيدة، لكن هنالك

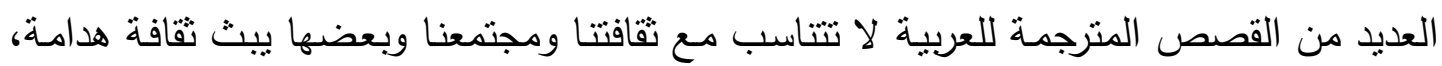

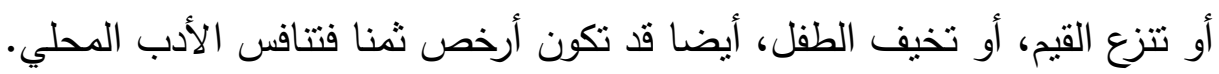

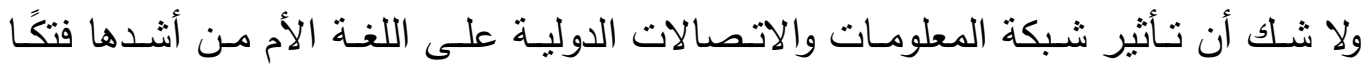

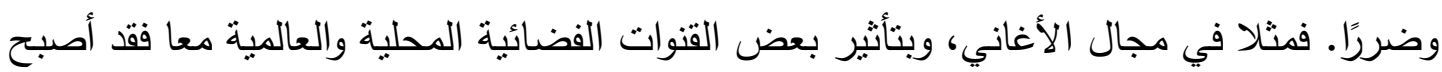


الأطفال يرددون أغاني الكبار ، ويقومون بالحركات ذاتها التي يقوم بها المغنون والمغنيات فضلا

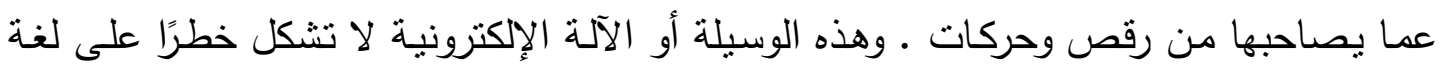
الطفل وحسب، ولكنها تسلب منه كل شيء، حتى أبويه وعقله وضميره، فهي وسيلة تفرض نقافة واحدة على طفل الغد، من خلال حصره في أنماط عيش ومناهج تفكير محددة مما"يؤثر في منهج التفكير عنده مستقبلا، ويكوِّن لديه عادات قرائية وسلوكية لا تخدم انتمائه وهويته"(عَ). والنقد هنا ليس هدفاً، بل وسيلة إلى تعديل صيخة الإعلام الموجَّهه للطفل، وهذا التعديل هو الغرض الذي أحاول تحقيقه.

وعلى الرغم من هذا كله لا ينبغي أن يصدنا بحال من الأحوال عن الانفتاح المدروس على التقافة الإنسانية في مجال أدب الطفل، بـل ثمـة مـاهو إنساني لا يصطدم مـع القيم والتقاليد ولا يحاربها. ويمكن من خلال هذه الأجهزة المنطورة تعزيز اللغة لدى الأطفال إذا تم إصدار برامج لغوية منطورة فيها إبداع تعين في هذا المسار • وما يُعْرَض على الشاشات ليس سيئا برمنه، فهناك الجانب الإعلامي التقفي الذي يسعى إلى نشر المعرفة وتعميم نفعها، ويُوَظف وسيلة لخدمة الأهداف الدينية والوطنية والإنسانية عامة.فمثلا أسهم التلفاز الفرنسي والإيطالي في تشجيع القراءة وتوسيع الكتاب خـلال العقود الثناثـة الأخيـر مـن خـلال بـرامج(فاصـلة،وبين قوسـين ،وحساء التقافة)،كمـا أسـهم أيضا في زيـادة شهرة الكتاب والمفكرين ورفع شـأنهم في المجتمع،كـا زاد برنامج(Book clup) الذي كان ييثة التلفزيون الأمريكي في عدد مبيعات الروايات..(ro) ولا ننكر مـا تقدمه الفضائيات العربية من قنوات وبرامج مخصصة للطفل مثل قناة اقرأ التي تتتقي مـا تقدمـه للأطفـال مـن بـرامج هادفـة تراعي القم والأخـلاق، فضلا عن البرامج التققيفيـة الموجهة لهم، والقناة الفضائية المصرية التي تقدم(عالم الأطفال) وأفلام الكرنون في القنوات العربية كافة، فضلا عن قناة الشارقة الفضائية ببرامجها النتقيفية المتتوعة. المهم أن ندرك أن ما يُعرض النه على شاشـات الأجهزة من عمل إيجابي ونماذج طيبة ينعكس على الطفل ولغته ويستثير دوافع 
الخير والفضيلة فيه، ويساعده على القيام بدوره في المجتمع بتتمية وإذكاء روح العلم والمعرفة في نفسه.

ويلاحظ أن وسائل الإعلام الحديثة ومنها شاشات الفضائيات أصبحت شريكا ومنافسا خطيرا للأسـرة والمدرسـة في تربيـة الأطفال؛ لذلك يجب ألا يُترك الحبل على الغارب للطفل لكي يقرأ ويشاهد ما يشاء دون رقيب من الأسرة التي يجب أن تقوم بمسؤوليتها في التخفيف من حدة الآثار المدمرة لتلك الثاشات ، وتوجيهه نحو الاعتزاز بلغته وقيمه وتراثه وأعرافه في ظل تقبل أب ثقافة خارجيـة قد تكون نافعـة أو ضـارة لله، وأن يُعَلَم أو يُربسى على أن يكون فـاعلا وليس سلبيًا في وهي التواصل مع الآخر ، ويؤصل فيه معاني الخير، وتعزز فيه التربية الروحية بحيث يقبل على التطور المدني والتقني المعاصر لييقى على توازن وقدرة على التواصل السريع مع هذه المتغيرات الحديثة؛

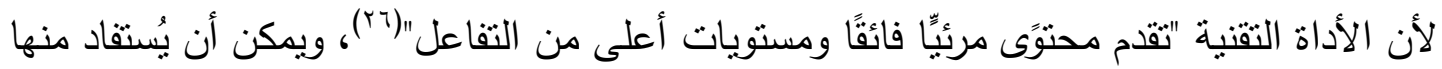

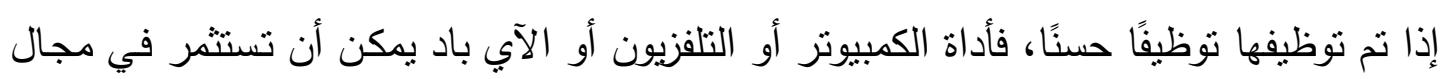
تعزيز مهارة القراءة من خـلال التدريب والممارسـة عبر الشاشة أو المدرب، أو تدمج في برامج الترفيه أو أفلام الكارتون.

\section{الإعلام وأدب الطقل :}

نحن في حاجة ماسَّة إلى رؤى جديدة وأدب جديد لطفل اليوم،ينتمي لهذا العالم الجديد الذي تخلق بين أيدينا،عالم الغرف المغلقة والإعـام الفضائي وقواعد المعلومات وانتششارها المتسارع، فهل ترتفع هذه الاستجابات "بأدب الأطفال إلى مستوى مسؤولياته الكبرى كأداة رئيسية في بناء شخصية صناع المستقبل في القرن لجديد؟!"(rV). إن أدب الطفل لا يختلف عن أدب الراشدين من ناحية البناء النصي قصة أو مسرحا أو شعرا أو أغنيـة أو عملا إعلاميا، كمـا أن أهدافه واحدة، فهو يقوم على المتعـة الجماليـة والتسلية إلى الى جانب كثير من القضايا والقيم الأخلاقية والتربوية. ومن شروط أي عمل يُقدم للطفل أن يكون رفيع 
المستوى، ويتمتع بقدرة حقبقية على إثارة خياله، وتحفيز آليات تفكيره، وتمكينه من تتمية قدراته اللغوية حتى يثبت تميزة وتفرده، وذلك بتوفير البرمجيات التعليمية باللغة العربية وتعليمه إياها،

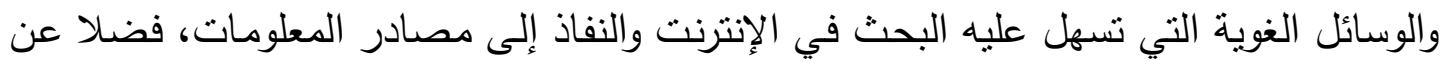
دور وسائل الإعلام المختلفة في تتمية قدراته. فقوة الأمم وحضارتها تقاس بمدى اهتمامها بدراسة تقافة الأطفال وأدبهم وعلومهم.

ولا شك في أن هذا يقتضي تمثيلا حقيقيا لعوالم الطفولة بلغتها المتميزة وبساطنها وخيالها

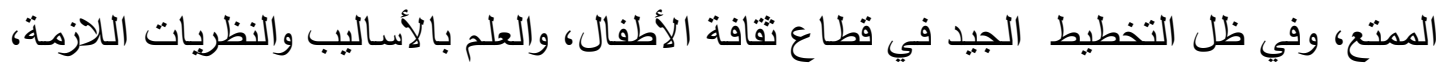
والاستتاد إلى مجموعة المعارف والخبرات والتتسيق والتعاون الكامل بين مختلف الدجالات التي

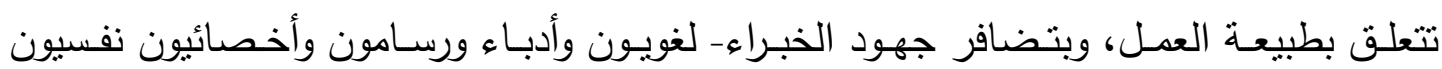

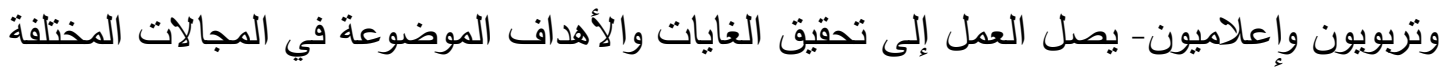

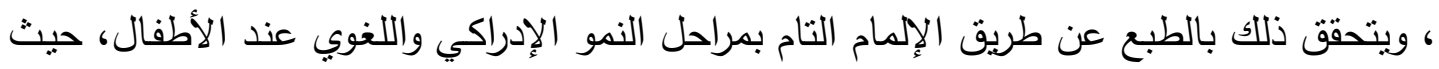

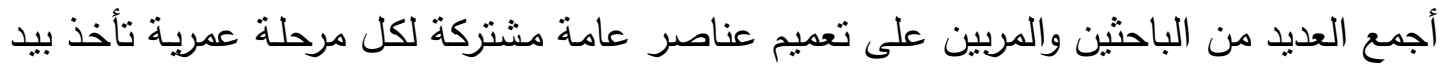

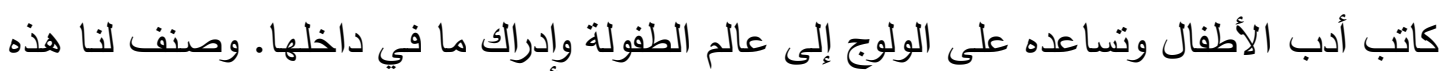

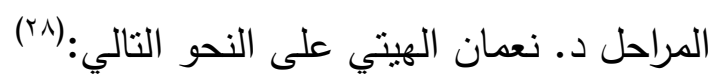

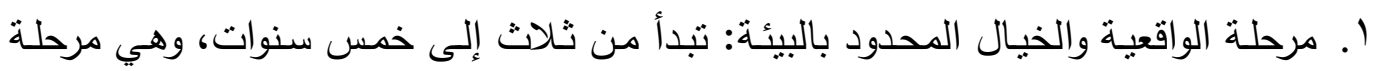
تكون فيها حركة الطفل محدودة في إطار منزل العائلة والمحيط الصغير بما يحمله من دمي وملابس وطعام وحيوانات أليفة نحيا قريبة منه، والطفل في هذه المرحلة كثير الأسئلة يقلد ويحاول التطبيق. ومن أهم عناصرها:الإيقاع والصوت والحركة والألوان.أما من حيث اللغة، فالاهتمام ينصب على موسيقى الكلمات والعبارات المسجوعة، وفي هذه المرحلة لا تتاسب الأطفال قصص الجن والسحرة، والخوف والعفاريت،أو ما يثير القلق

$$
\text { والحزن لايهم. }
$$


r. مرحلة الخيال المنطلق: تبدأ من ست إلى ثمان سنوات، وهي مرحلة ينمو فيها الخيال،

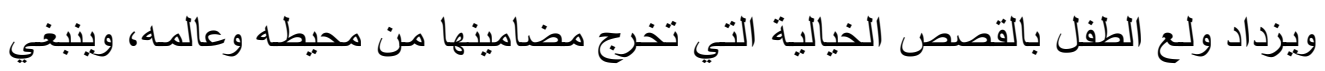
على القصص الموجهة لهذه المرحلة أن تراعي المغامرات.

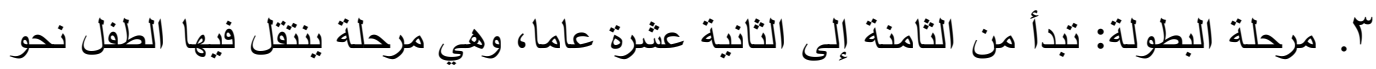
الاهتمام بالحقائق،وتستهويه قصص الثجاعة والمخاطرة والعنف،والمغامرة، وسير الرحالة والمكتشفين،بالإضافة إلى القصص الهزلية والقراءات المبسطة وكتب المعلومات . ؛. مرحلة المثل العليا:تبدأ من الثانية عشرة إلى الخامسة عشرة عاما، وهي مرحلة الاستقرار العاطفي النسبي،وهي مرحلة دقيقة وحساسة، يميل فيها الطفل إلى القصص التي تمتزج المغامرة بالعاطفة،وتقل فيها الواقعية،وتزيد فيها المثالية؛ فالثخصيات الرومانتيكية ستكون جذابة، وكذلك القصص البوليسية والجاسوسية والحب. ومن ثم فيجب أن نكون على وعي تام بما نقدمه للطفل، فالهدف المنشود لا يتحقق بمجرد

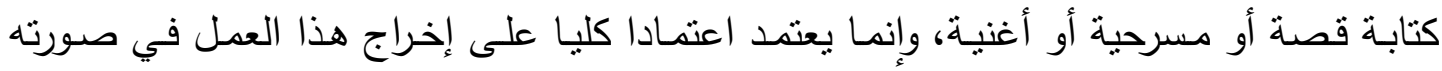

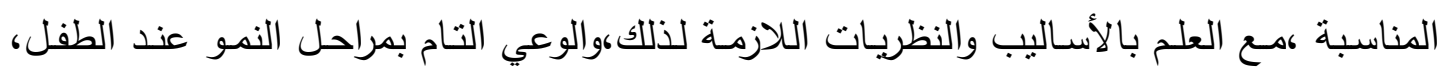
والمراحل النفسية التي تميز كل مرحلة. إن مجموعة المعارف والخبرات التي تتعلق بطبيعة العمل يجب أن تقوم على معرفة لمن نكتب؟ وماذا نكتب؟ وكيف نكتب؟. كما يجب أن نكون على وعي كامل بمراحل النمو عند الطفل-

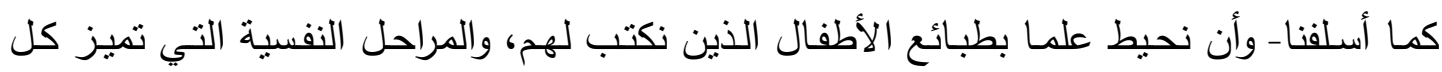
مرحلة.. فالكتابة في ميدان القصة تختلف الاعتبارات الفنية والتربوية في أنواعها، فمن الفكاهة الفانة

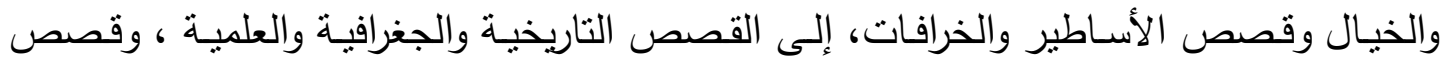

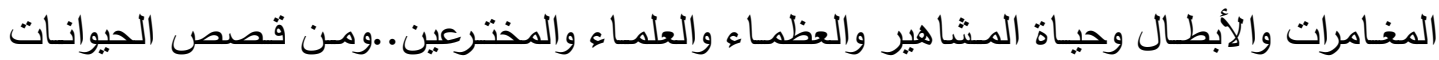
الناطقة والقصص العالمية الدبطة، إلى غير هذا وذاك من أنواع القصص التي يزخر بها عالم 
الأطفال. أما المسرحيات فتكون تثقيفية تعليمية أخلاقية(؟9). هذا بالإضـافة إلى الأغاني وبرامج الإذاعة، وأفلام الكرتون والسينما وغيرها.

وتخضع الكتابة في طبيعة العمل المقدم للطفل لمجموعة من الاعتبارات منها: الاعتبارات

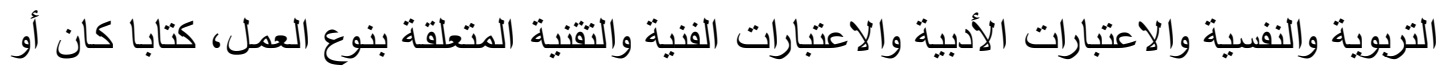
مسرحا أو وسيلة إعلام.

ويُلاحظ أن بعض ما يقدم في أدب الطفل من قضايا تخص الطفل قد اتخذ مسارا وعظبا مباشرا لا يختلف عن أي درس يتلقاه في المدرسة، مما يفقده المتعة والسعادة التي ينمو من خلالالها

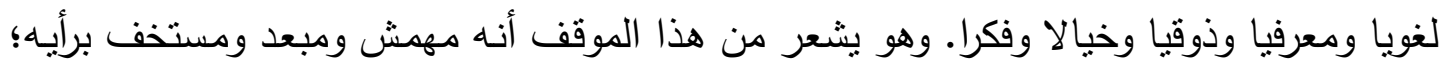

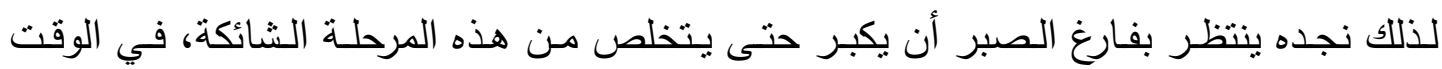

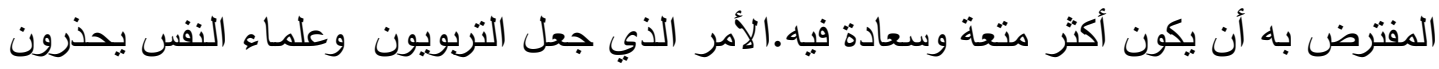

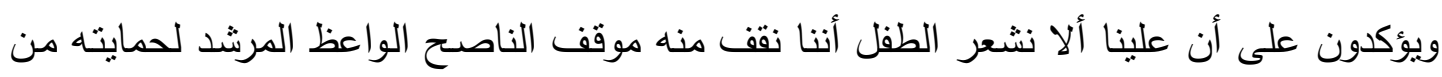
الصدمات الإنفعالية والوجدانية.

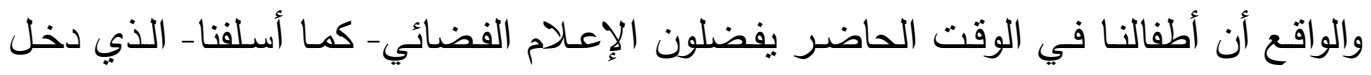

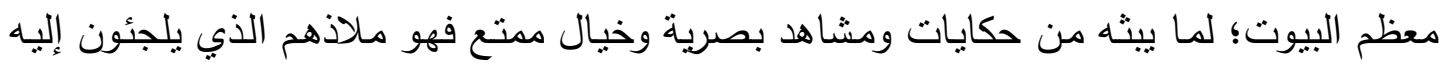

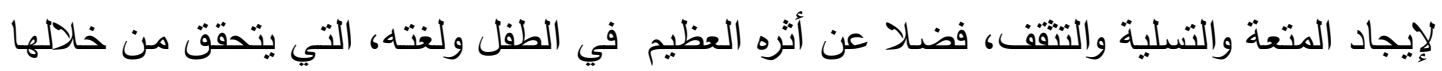

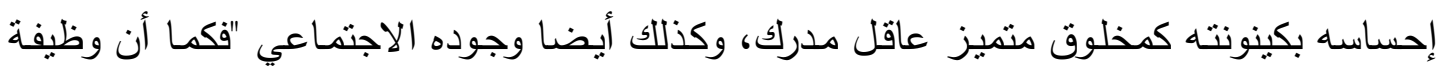

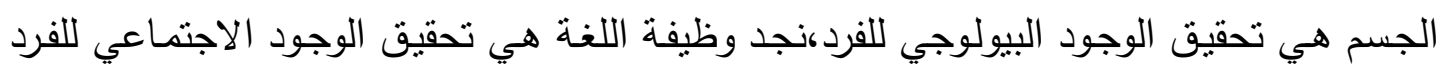

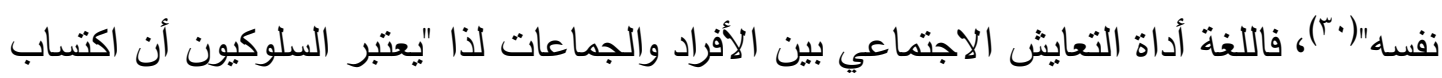

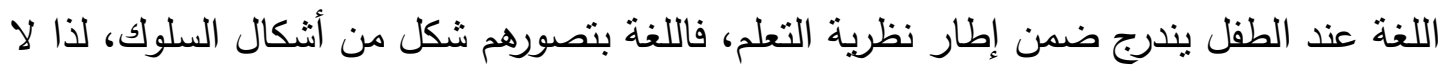

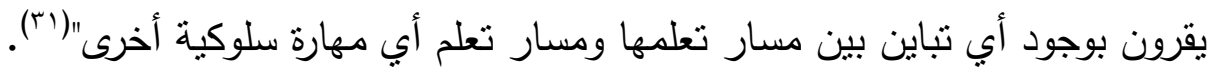

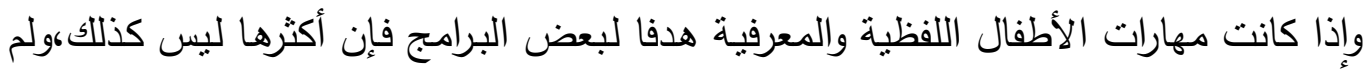
تعرض للهدف ذاته. ففي دراسة قام بها فريق بحث من مؤسسة (راسل ساجا) في الولايات المتحدة العال 
الأمريكية لمعرفة أثر برنامج "ثارع السمسم"أكدت النتائج أن مهارات الأطفال اللفظية والمعرفية-

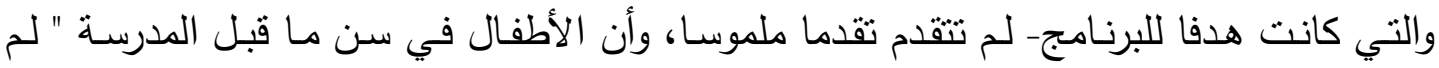

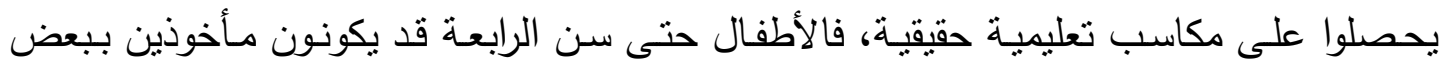

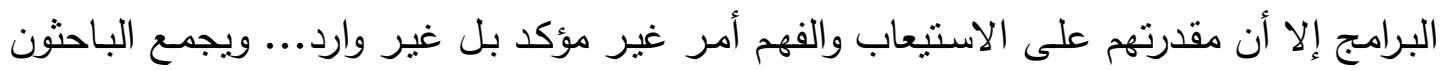

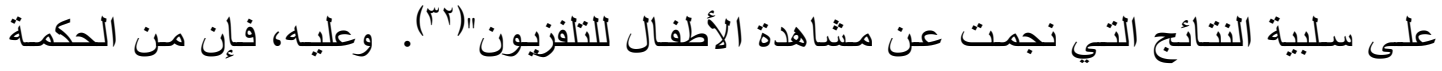

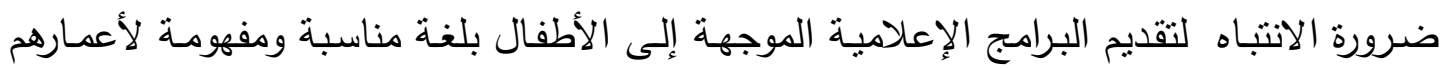

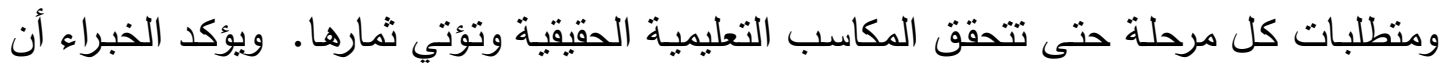

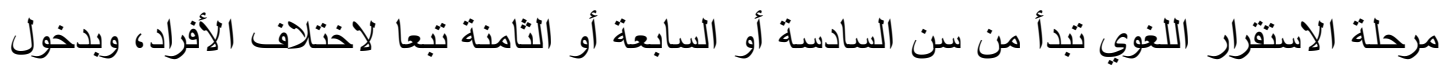

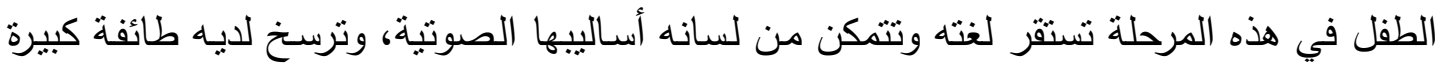
من العادات الكلامية لطبيعته الخاصة"("rr) . ومهما يكن من أمر ، فإن أن اللغة العربيـة ليست أداة للاتصال والفكر واكتساب المعرفة

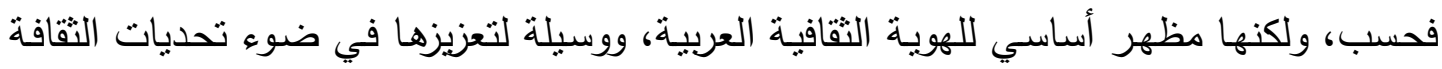
الأجنبية المتلاحقة، فضلا عن تعاظم دور القوى والمؤثرات غير المقننة مثل الإعلام الفضائي

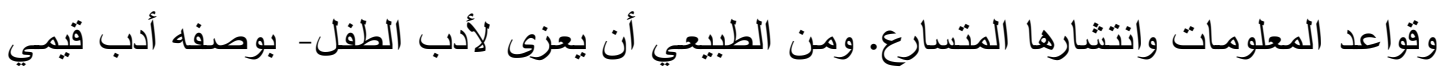

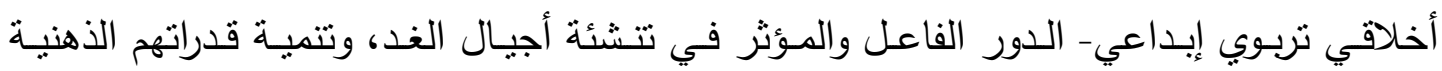

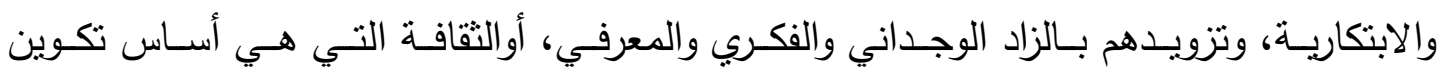

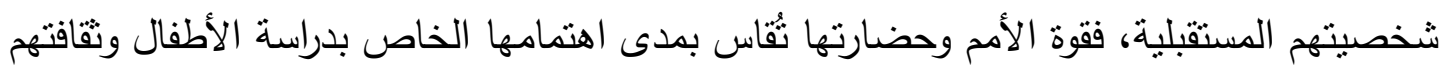

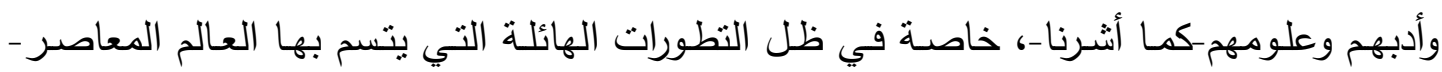

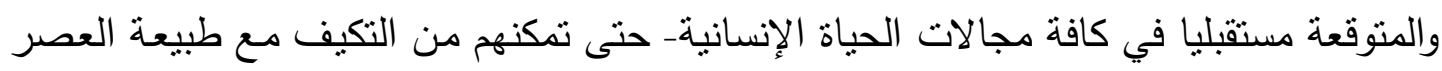
الذي يعيشون فيه وتؤهلهم للعيش والقيام بواجبهم المجتمعي مستقبلًا.

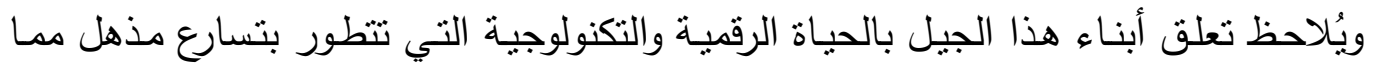

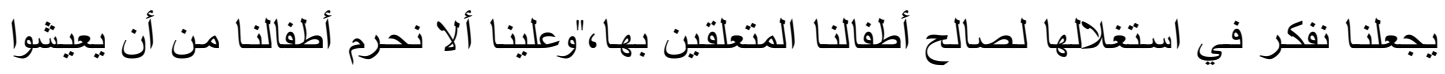


العصر ويعايشوه منتبعين.. ومشاركين فيه"(ז"، فمن"حق طفلنا ألا يكون معزولا عن هذا العالم.

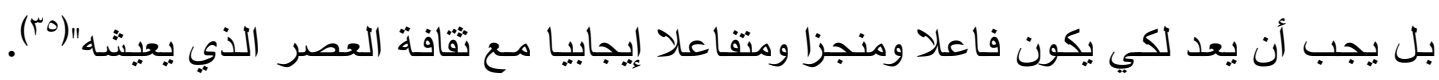

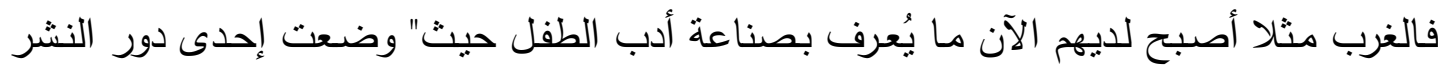

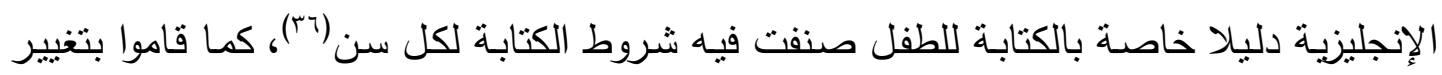

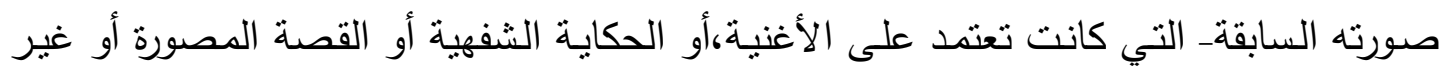

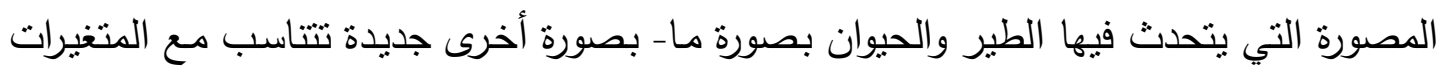

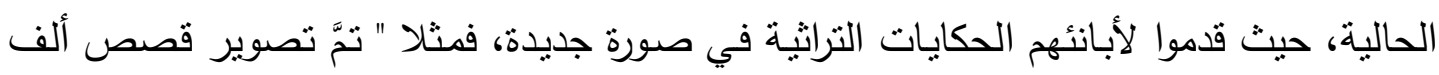

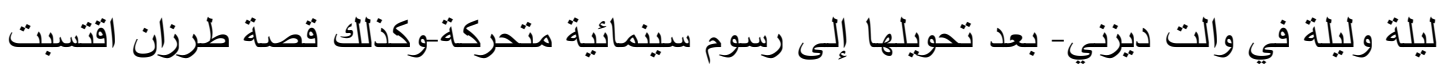

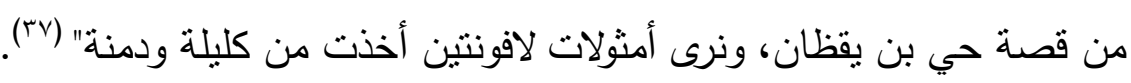

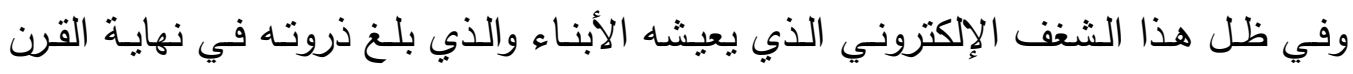

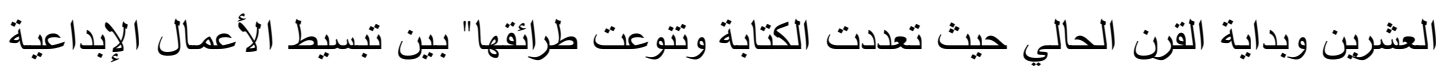

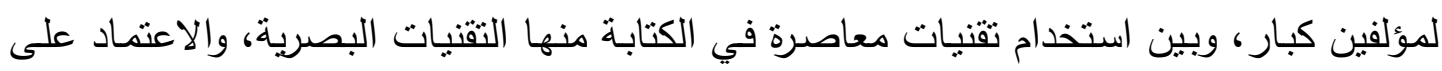

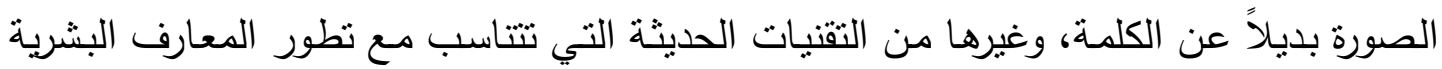

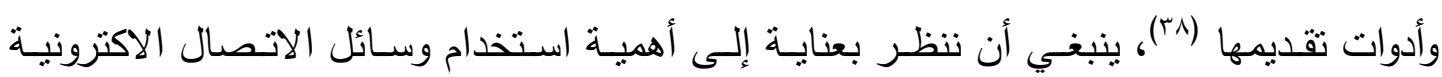

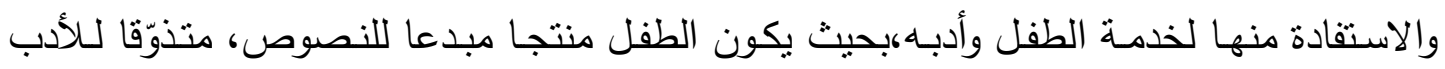
والفنّ، ناقدا.

ولذلك يجب إنشاء أدب جديد يقديم عرضـا تفصيلا عن مفهوم القصة الرقميـة ومميزاتها وعناصرها وطريقة عملها، والخطوات التي يجب اتباعها لإنتاج -على سبيل الدثال- رواية أدبية

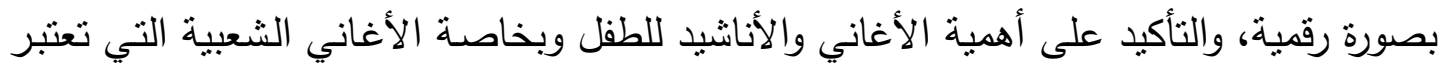

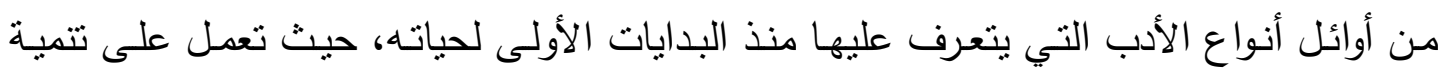

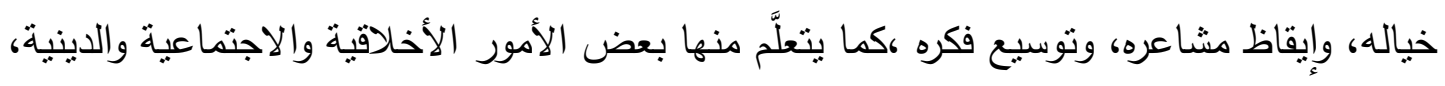

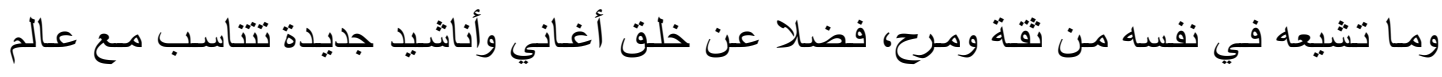


الحجرات المغلقة والتلفزيون والكومبيوتز ، كما يجب الاهتمام بالرسوم التي يتم إضافتها في الكتب الخاصة بالطفل؛لأسر لبه وتحبيبه بالكتاب، فالرسوم المتحركة تعتبر وسيلة مهمة لنقل التراث له، وبالطبع ينت ذلك من خلال الصورة والحركات التي ستجذب الطفل، إضـافة إلى الحوار الشائق والمؤثرات الصوتية، مما يجعل هذا التراث ينتقل من مجرد كلام على الورق أو حديث شفهي متنقل إلى كلام مصور يتعايش معه الطفل وكأنه واقع يشاهده أمامه. وعليه، فإن أدب الطفل والنصوص المدعمة بالوسائط المتعددة أصبحت تلعب دورا فعالا في هذا المجال؛ فهي تغذِّي النصَّ وتحييه، ويمكن استخلالها لإعادة إنتاج النتاج الأدبي بسياق إلكتروني أكثر تشويقا في ظل هذه الثورة

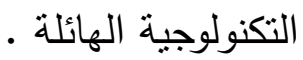
ويعد التعليم:هدفا رئيسا من أهداف أدب الطفل ووسيلة أساسية يتم من خلالها تزود الطفل بالمعلومات والمهارات التي تساعده الإحاطة والتفوق في العصر الجديد؛لذا ينبغي تطوير بنيـة ومناهج الأنظمة التعليمية، بحيث تستوعب جميع الأطفال في سن المدرسة، والاهنمام بمعلميهم وإعدادهم إعداداً جيداً في حقل اللغة العربية. مع وضع مخطط علمي لمنهج منكامل قائم على استعمال اللغة بدلاً من التركيز على دراسة القواعد المجردة، يبدأ بمرحلة ما قبل المدرسةهوالتشديد في شـروط القبول للجامعـات وكليـات إعداد المعلمين على موضـوع اللغـة، وتزويد المؤسـسات التعليمية بالإنترنت وأجهزة الحاسب الآلي وتطوير أساليب تعلم اللغة العربية السليمة من خلالها للطلاب غير القادرين على اقتنائها،"بمـا يضمن تحسين نوعية التعليم وتهيئة الأطفال لمجتمع اليوم،والعمـل على تطوبر مهارات جديدة مـن شباب المستقبل، فـالتعليم الإعلامسي أو استخدام

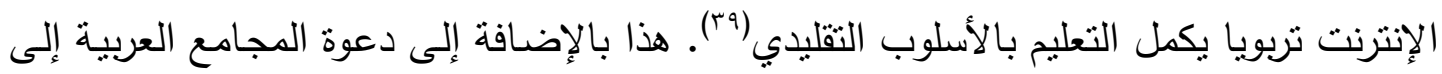

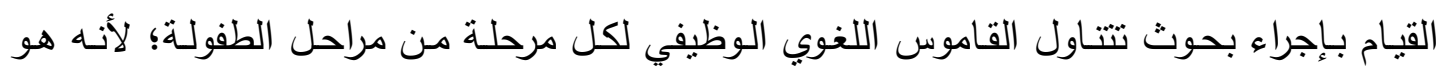
الأساس الذي ينبني عليه إعداد المناهج المدرسية وتصنيف معاجم الأطفال. وفي هذا المجال نود أن نهمس بكلمة وهي: أن أهم أسباب تدني مستوى اللغة العربية على العى ألسنة النشء والصغار يرجع إلى عوامل عدة منها: المسلسلات والأفلام الناطقة باللهجات المحلية، 
فضلا عن طغيان اللغة الإنجليزية وانتشارها الذي يؤدي إلى انحسار اللغة العربية(•؛؛ لذا يجب على الأسرة أن تقوم بمهمتها-كما أشرنا-للحد من الآثار المدمرة للإعلام الفضائي، وذلك بمشاركة أطفالهم مشـاهدة برامجـه، وانتقاء البرامج المناسبة لهم، والعمل على مناقشة المـادة المعروضـة

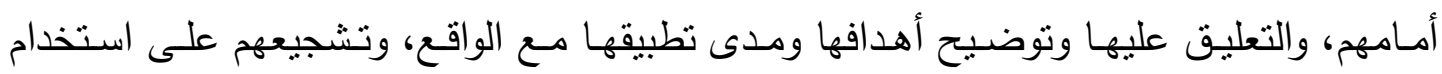
قدراتهم النقدية أثناء مشاهدتهم للتلفزيون. كذلك عليهم أن يحددوا لهم أوقات لمشاهدته، فتمنعهم من مشاهدته إلى ساعات متأخرة من الليل، وتشجعهم على أنشطة أخري كالمطالعة وسماع الراديو، واللعب مع الأصدقاء وممارسة الرياضة، لنضمن لأطفالنا السلوك الاجتماعي القوبم ومنه السلوك اللغوي.

وإذا أدركنا أن الإعـلام كذلك يسهم بدور فاعل ومؤثز في تقويم لسان الطفل وتشكيل عقله وتوجيه سلوكه وأدبه ولغته التي هي كيانه، ألزمنا ذلك بضرورة اعتماد اللغة العربية لغة للبرامج المخصصة للطفل في وسائل الإعلام المرئية والمسموعة ، و الاهتمام بما يُيث من خلاله من إنتاج تعليمي وترفيهي ومواد مترجمة؛ لأن الطفل مقلد لما يرى ويسمع ويرتد ذلك على سلوكه بأكمله، و على رأس ذلك اللغة، مع الحرص على عرض نلى نلك المواد بطريقة جذابة وشائقة وفرض نوع من

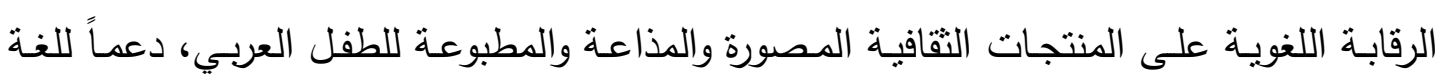
العربية، فضلاعن إنتاء المزبد من القنوات الهادفة المخصصة كلياً للطفل على أن يكون التداول فيها بالعربية، وإلزام الإعلاميين بالعربية الفصحى على الأقل في برامج الأطفال، وتوجيه برامج

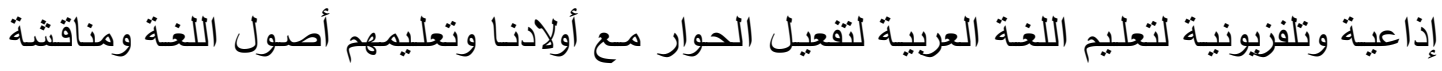
القضايا الثقافية والتراثية بصفة مستمرة. مع منع استخدام غير اللغة العربية في الإعلانات بجميع أثكالها، وإعادة النظر في كل الإعلانات التي تقدمها شاشات الفضئيات، وخاصة الموجهة للطفل، وأن يتم تقديمها بلغة عربية صحيحة مبسطة وسلسة ، وكلك أيضا منع مشاهد العنف والإرهاب والجريمـة في مشاهد الأفلام والمسلسلات وأفلام الكرتون،لأنها تنعكس سلبا على نفسية الطفل وتغرس فيه نزعات شريرة وعدوانية،حيث يقلد ما يشاهد، فتصبح كل ألعابه وعوالمه عنفا وإرهابا، 


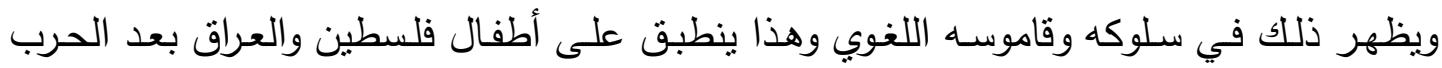

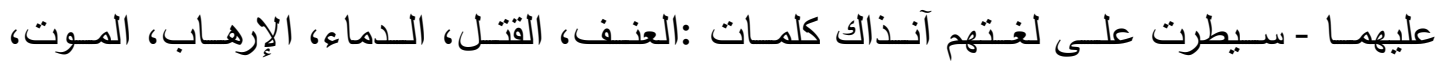

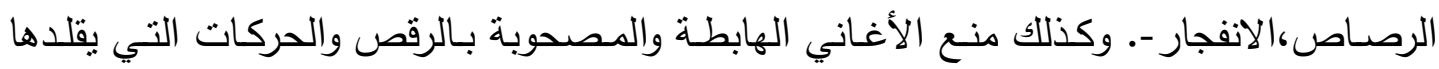

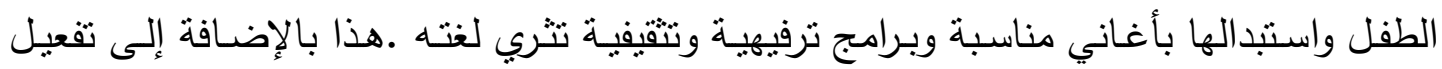
المسابقات في مجال أدب الطفل العربي باللغـة الفصحى مـن خـال وسـائل الإعـام المختلفة

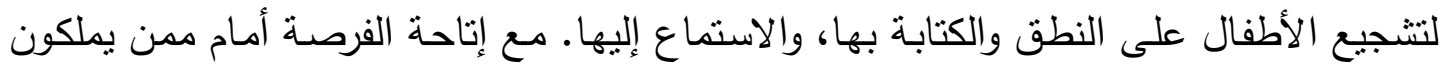

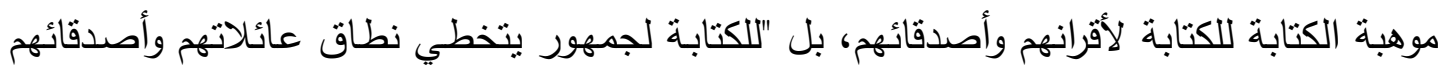

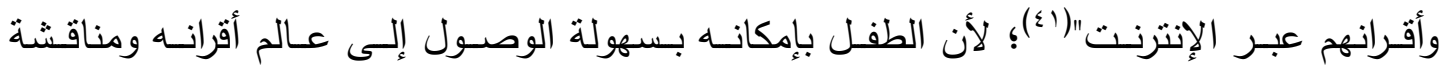

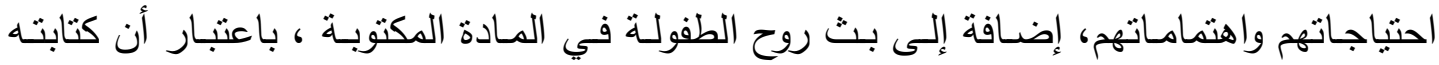
للطفل أكثر مصداقية.

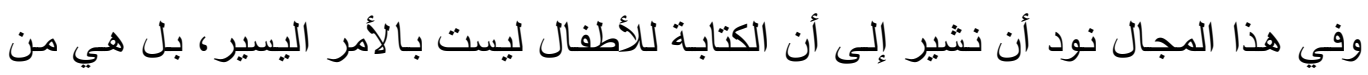

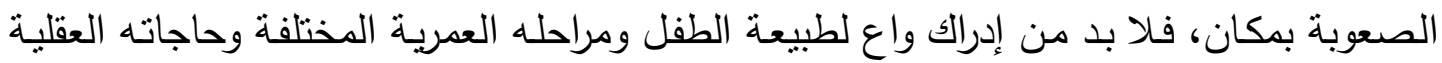

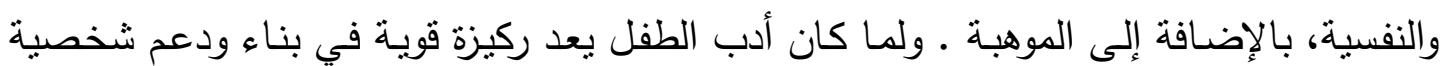

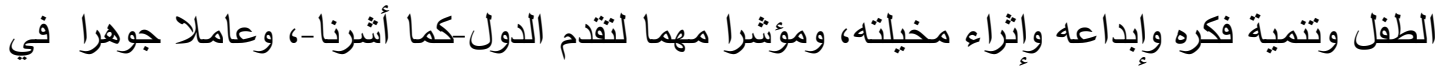
بناء مستقبلها، بات من البديهي البحث عن فكر جديد يتتاسب مع نطلعات طفل العصر الحديث،

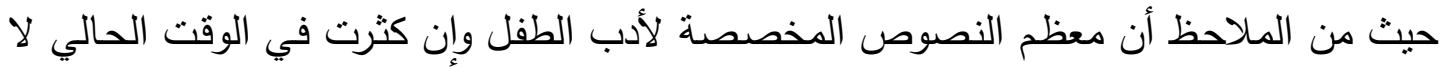

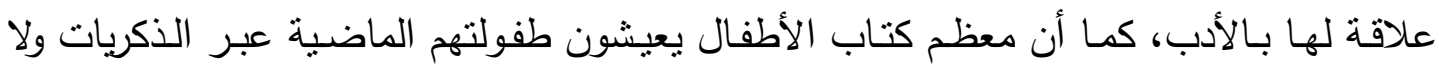

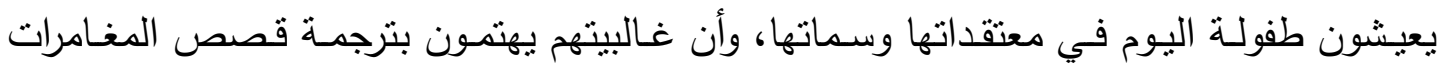
مثل (السوبرمان والرجل الأخضر وباتمان وغيرها) والقصصص البوليسية التي تقدم الدتل الأعلى التى في صورة المغامرين واللصوص والجواسيس-مما يناقض قيمنا وعاداتتا ومُتلنا العليا-، ولا يهتمون الفيان

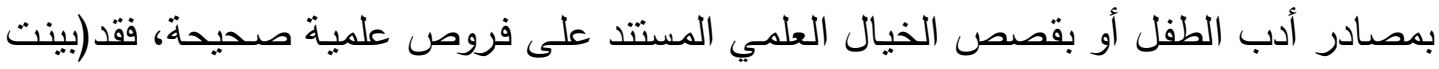

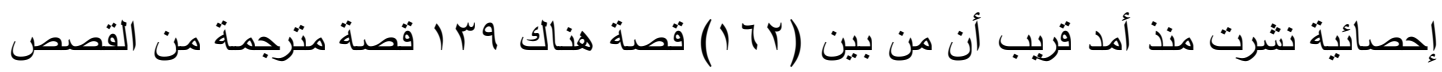




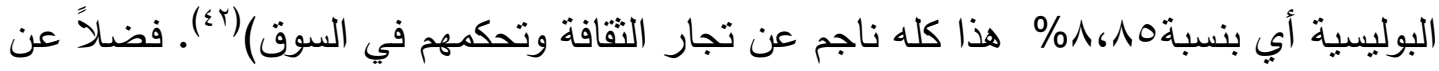

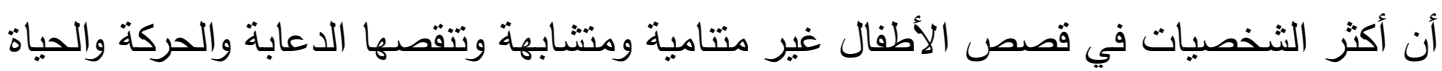

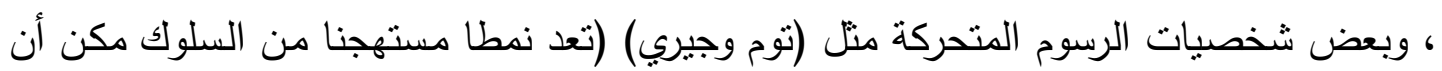

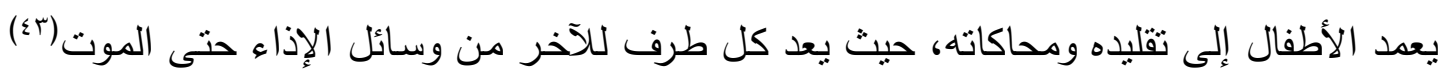
،كما أن معظم القصص تفتقا إلى الإثارة وبعضها حافل بالأخطاء اللغوية والنحوية.

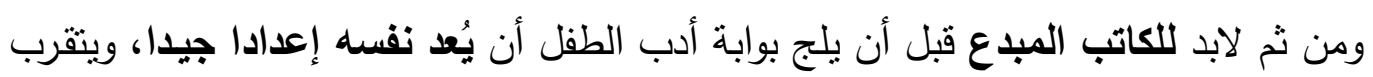

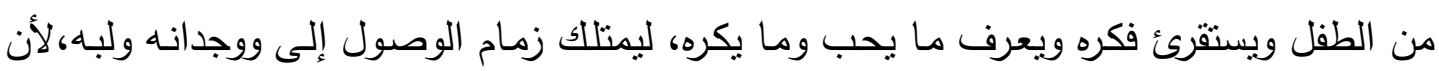

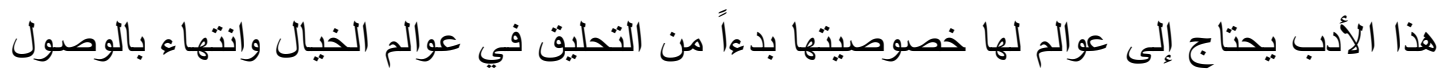

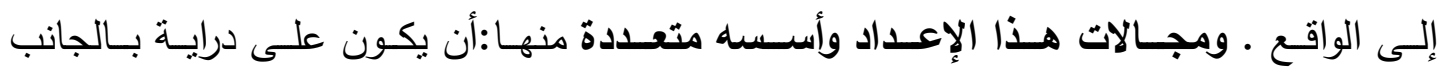

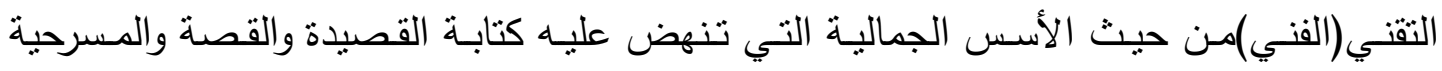
وملائمتها لمراحل الطفولة المختلفة، ذا ثقافة تربوية واسعة، ملما بعلم نفس الطفل الطف ومعجمه اللغوي

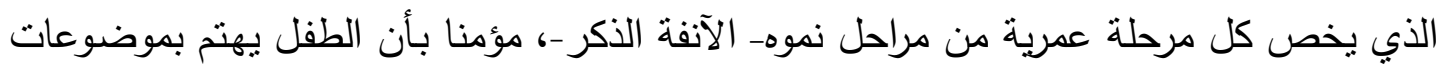

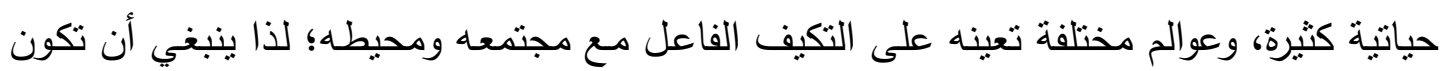

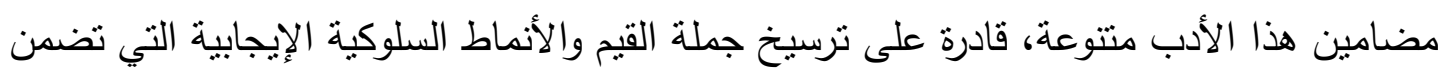

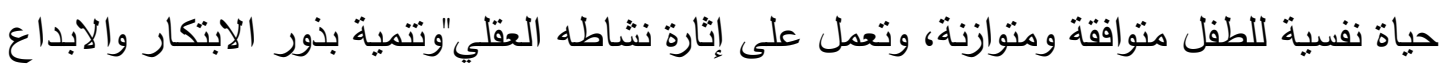

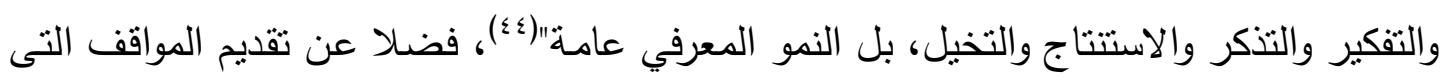

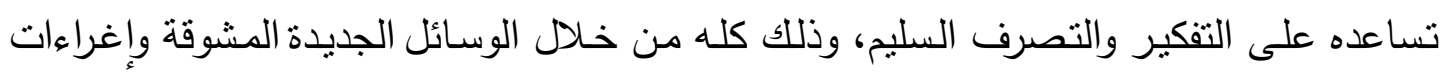

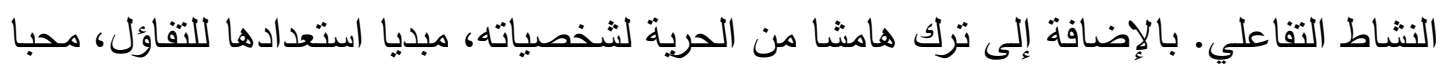

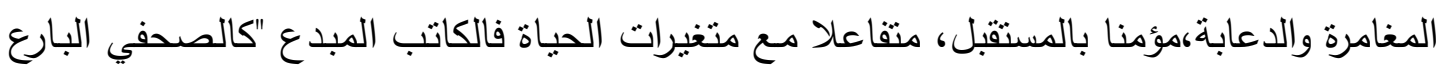

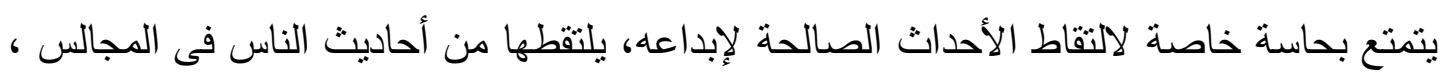

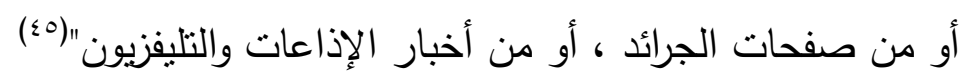


وليس هذا فحسب بل يفترض أن يعرف الكاتب أن هذا الأدب ليس حشواً للعقول الصغيرة، بل

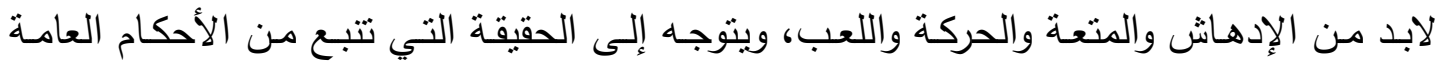

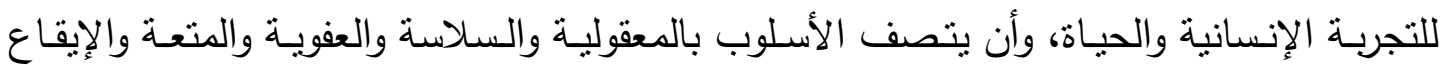
والتتاغم، ويجب على الكاتب أن يحسن اختيار الأحداث، وأن يهتم بالخيال العلىي-من الأساليب

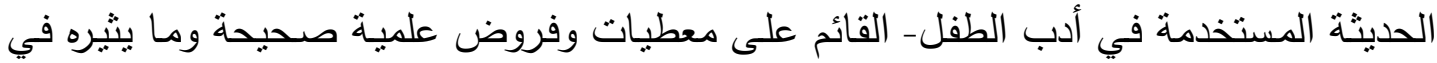

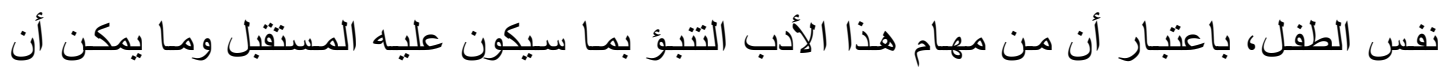
يتضمنه من مخترعات، مـع الحفاظ على الأصيل مـن الموروث الشعبي والثقافي في الأدب، وتجسيده لربط الحاضر بالماضي والانطلاق بـه إلى مستقبل أفضل، والاصـرار على استمرار التجريب ومتابعة التنظير ، مما يؤدي إلى تعميق المضمون وإناحة الفرصة للتعبير عن المعارف.

\section{مهارات (تصال أدب الطقل :}

تعددت بتعدد نمو تفكير الطفل، والتطورات الصناعية السريعة والتكنولوجية التي أدت إلى إبى

ابتكار طرق جديدة مُحسَّنة لتقديم النصوص، ومن ألوانها: 1-اللعب: وتستثمر وسيلة اللعب باختيار الألعاب المناسبة التي يمكن للطفل أن يستخرج منها

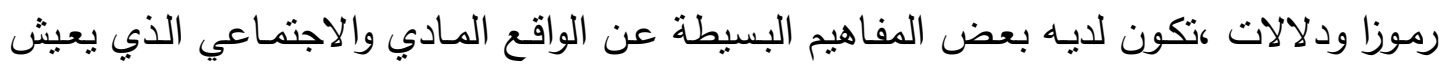

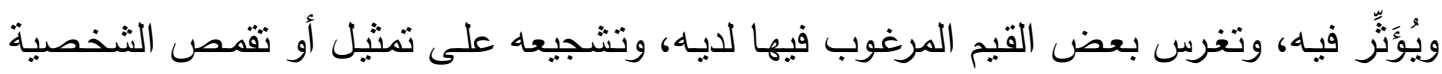

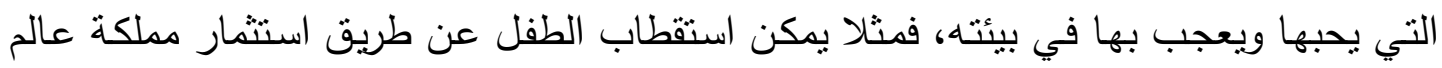

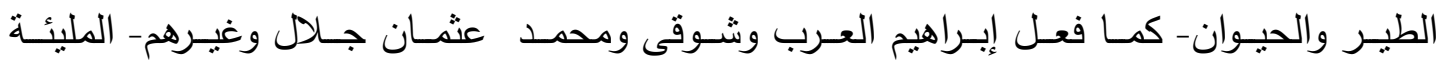

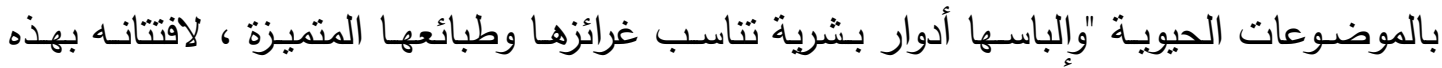

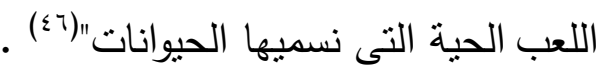
ولا ننسى ألعاب الكمبيوتر التي تأثر بها الطفل مؤخرا فهي تحقق لـه المحاكاة ، فيتمنلها

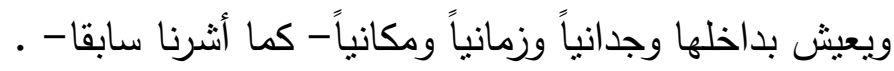


ץ-الكتب المـصورة المطبوعـة المتممـة للعب والمؤديـة إلى تكوين بعض المعارف والاتجاهـات بحيث تكون الصور مدروسـة ومنسقة على شكل بطاقات أو لوحات أو "ذات أثكال ورسومات

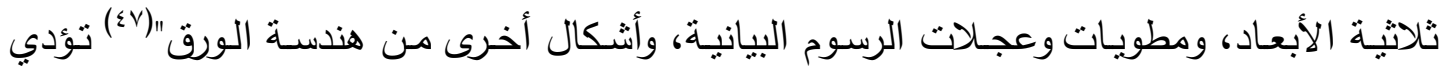
أغراض محددة .

ب- المشافهة سـردا وتمثيلا وتوجيهـا إذا كان العمل المقدم قصة أو مسرحية،هما يُعَوِّد الطفل حسن الإصغاء،وتركيز الانتباه لمتابعة الأحداث المسموعة ،كما يمكن إثراكه في تمثيل ذلله، أما في حالة الأنشودة فيستحب إشراكه في ترديد جمعي؛ لأن هدفها هومعالجة تردده وخجله، وتعويده على المحادثة والنطق ومشاركة الآخرين، وأيضا تقويم انحرافات النطق وتقوية العزائم وبعث الهمم لديه، فضلا عن إكسابه ثروة لغوية تلقائيا ودون عناء ع- المجـلات والـصحف الورقيـة والإكترونيـة: أمـا المجـات والصحف الورقيـة فهي مثل الكتب تستعمل الكتابـة والرسم والصورةهوتقدم للطفل المعلومات والمعارف، والقصص المصورة بأنواعها المختلفة، والتحقيق الصحفي، والأغاني والتمثليات القصيرة،والمسابقات الأدبيـة والتقافية، وغيرهـا

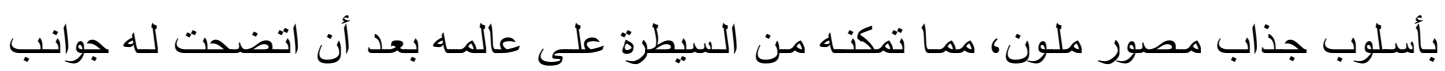
مجهولة منه، فضلا عن "أخبار الأطفال المحلية والعالمية،مع ألوان ونماذج مختارة من قصصهم وآدابهر عند مختلف الشعوب المعاصرة"|(^).ومن أبرز المجلات سمير وميكى اللتين تصدرهما دار الهلال بمصر ، وماجد العربية وغيرها. وأما المجلات والصحف الإكترونية، فهي ظاهرة ووسيلة إعلامية جديدة تلعب دورا رئيسا في تتكيل الاتجاهات والصور الذهنية لمتلقيها وبخاصة الأطفال حيث تمكنهم من الوصول والاطلاع على ما يريدون معرفته من فنون أدب الطفل وغيرها من أرشيفها في أب وقت وأي مكان، فضلا عن الإلمام بالمعلومات والمهارات وتكوين الرأي العام نحو القضايا والأحداث في المجتمع الذي إني يعيشون فيه،ويرجع تميزها" بعدد كبير من الخصائص التي اكتسبتها من السمات المميزة للإنترنت كوسيط اتصالي، من حيث استخدام الوسائط المتعددة والتفاعلية، كما أنها تعطي القارئ الفرصـة 
لقراءتها في أبي وقت يشاء وإمكانية تحميلها واسترجاعها، فضلا عن أنه تتيح فرصا كبيرة للجمهور

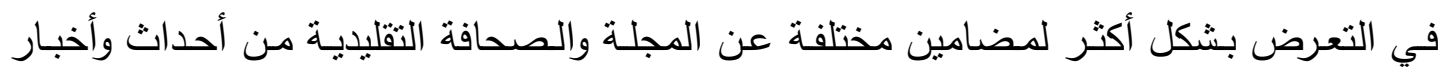

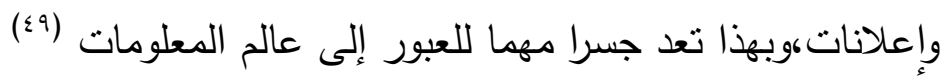

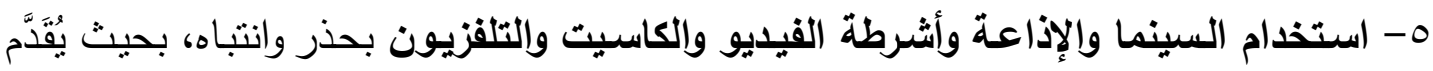

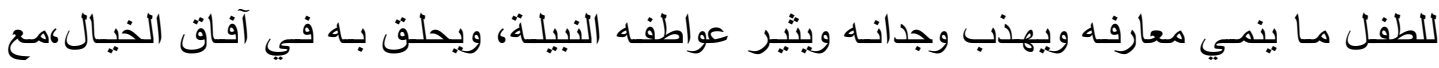
الابتعاد نهائيا عن الأفلام السينمائية والتلفزيونية والكرنونيـة الغربية ـالكاوبوي،السوبرمان،طرزان

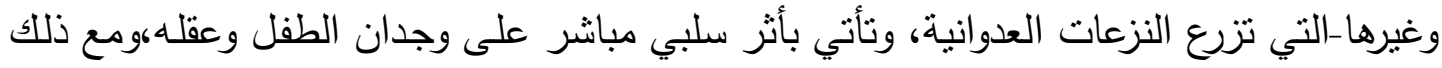

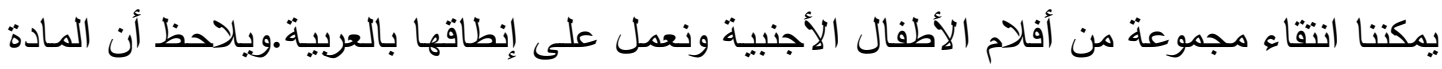

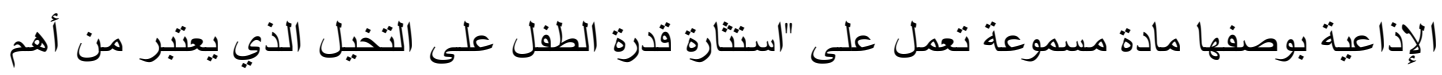

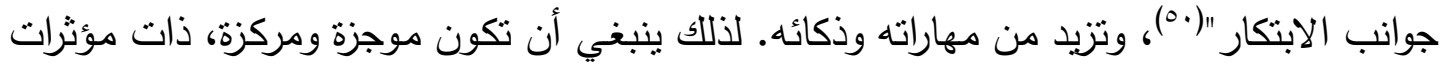

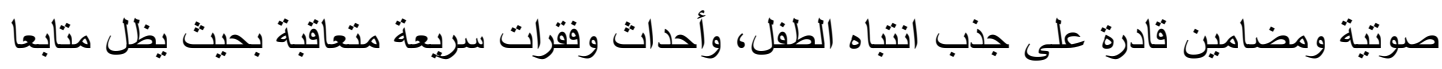

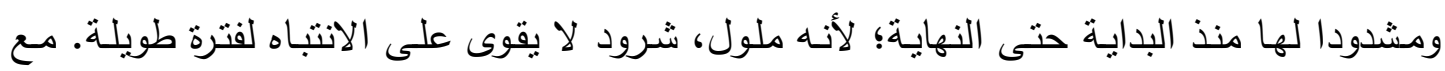

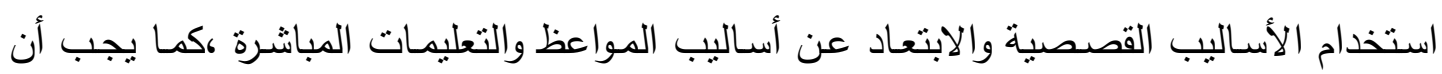

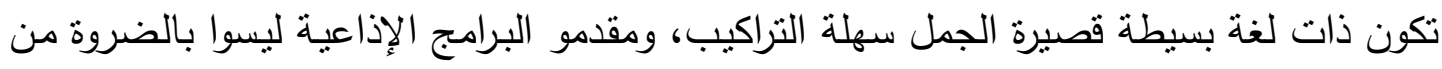
الأطفال، حيث نجح كثير من الكبار - بأصواتهم- في إقامة علاقات وطيدة بينهم وبين الصغية الصغار

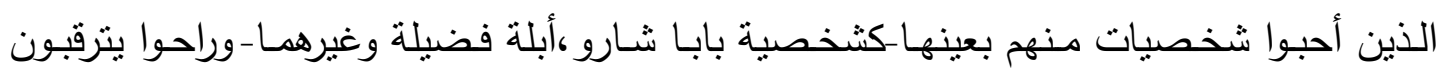

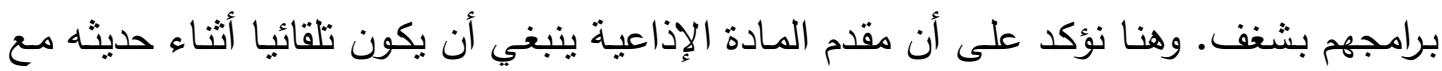

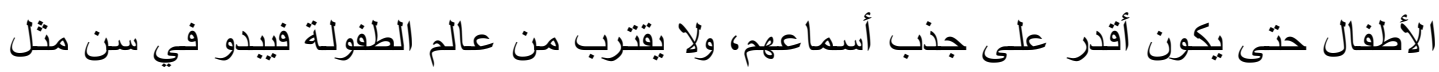

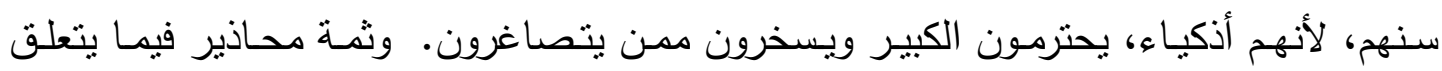

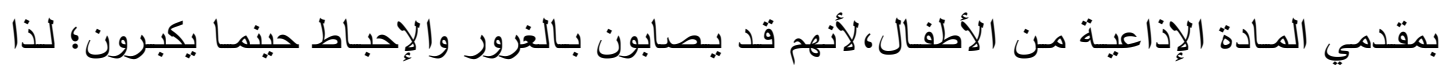
تحترس بعض الإذاعات من استخدام الأطفال إلا عند الضرورة. 
وجدير بالإثارة أن الإذاعة كوسيلة للاتصال الجماهيري ومنها جمهور الأطفال مرت بكثير من

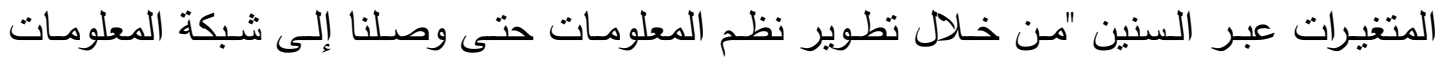
الدولية، حيث أصبح توفير الراديو على شبكة الإنترنت بمثابة ثورة في تاريخ وسائل الإعلام، العادئ والتعليم بدوره استفاد من التقدم التكنولوجي الجديد في إنتاج البرامج التعليميـة الإكترونيـة في لإي مجالات متعددة -ومنها مجال أدب الطفل-، وذللك في محاولة للخروج عن النموذج النقليدي للنعليم

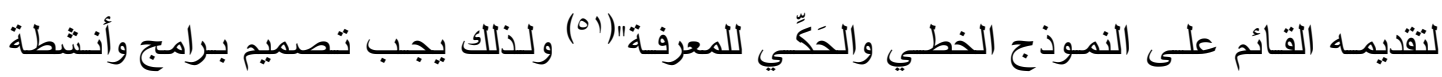
وفعاليات إكترونية لدعم منهج التعليم عامة ونصوص أدب النعاب الطفل خاصة.

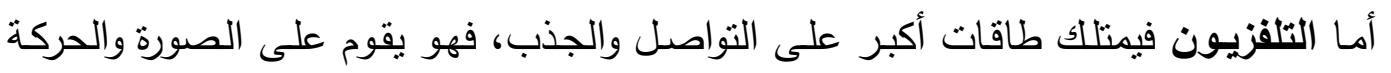

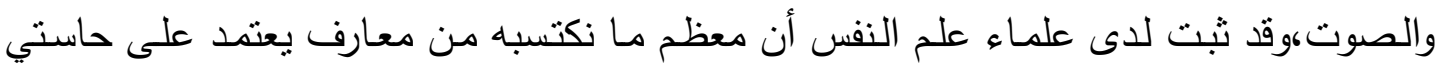

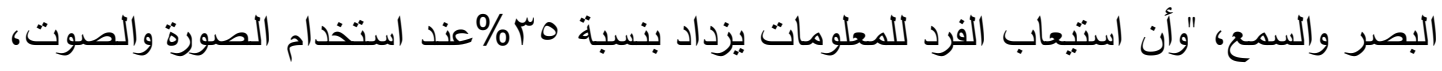

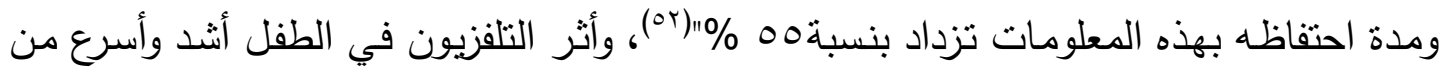
تأثثره في الكبار ؛ ولذللك فإن أغلب وقت الأطفال يقضونه بالقرب منه ، حيث ينقل لهم أنماطا

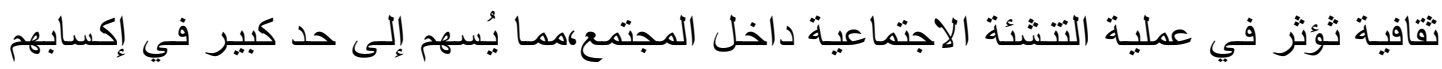

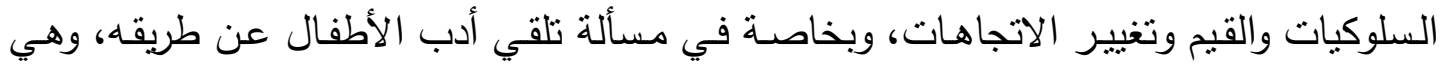
تبدو" عملية بالغـة النعقيد تجهـع بين احتياجات وانفعالات نفسية عديدة منها الكبت والإعلان

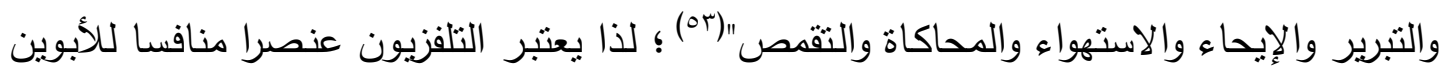

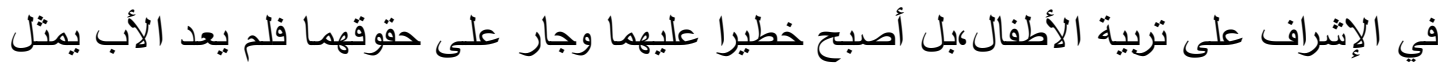

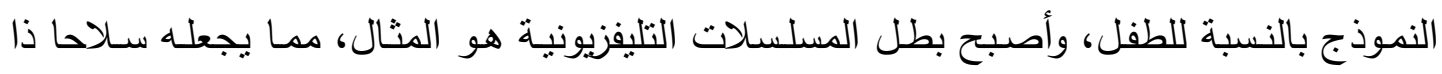

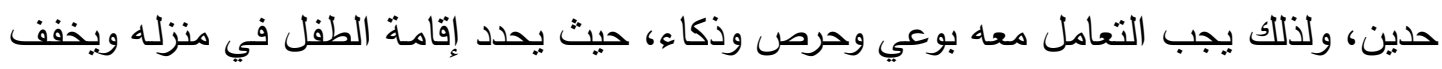
من اختلاطه بأقرانه مما يؤثر بالسلب نتيجة عدم استفادته من هذا الاختلاط ، بل قد يؤدي إلى لى غرس روح العزلة فيه والاغتراب الاجتماعى وما إلى ذللك. 
ولا ريب أن المادة التليفزيونية المقدمة لطفل تلبى الكثير من احتياجاته وعالمهه الخاص الذي يعيش فيه، وهي أكثرا تأثثرا من المادة الإذاعية، لما يمنلكه التلفزيون من طاقات وإمكانات؛ لذا ينبخي أن تكون منوعة، تُستخدم فيها المؤثرات الصونية والبصرية والحيل السينمائية، وقادرة على تتمية ملكة الخيال، وينتفي منها الخطاب الوعظي والتعليمي، فضلا عن أن يكون لها استراتيجية مدروسـة وواضـة. ويلاحظظ أن جزءا كبيـرا مـن رغبـات الطفل المعاصـر يشبع بواسطة صـور

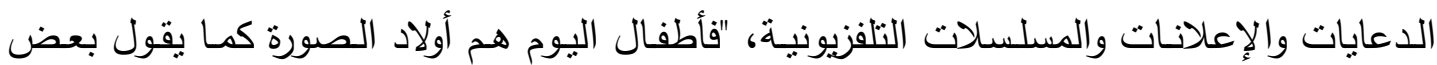

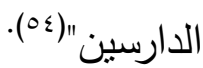

وطبيعي أن ندرك أن وضعية التَّتي-تلقي أدب الطفل- بالنسبة للتلفزيون تختلف عن وضعية التلقي بالنسبة للكتاب، فالمشاهد أمام الصورة يجلس مسترخيا،أما القراءة فتتضمن موقفا عقلانيا، فعلى القارئ أن يمـارس فعل إرادة،أن يختار الكتاب، ويوفر الظروف المناسبة للقراءة والتركيز الذهني، ويفك رموز الكلمات،فقد يعيد قراءة الصفحة مرتين أوأكثر، وقد يسطر تحت التي يعتبرها مهمة. وفي اللغة تكون العلاقة بين الدال والمدلول اعتباطية، ثم الاصطلاح عليها، فهي عرفية بالدرجة الأولى،أما بالنسبة للصورة فالعلاقة جوهرية، والرسالة تدرك مباشرة والصورة توصل دلالات قد لا يستطيع اللفظ التعبير عنها"(00).

\section{الخـاتمــة}

أبرزت دراسة الإعلام وأثنره في الطفل وأدبه عدة نتائج يمكن إجمالها على النحو الآتي: ا ـ بلغت التطورات الصناعية السريعة والمعلوماتيـة في مجـال الإعـلام والاتصال غايـات كبيرة وأصبحت وسائله المرئية والمسموعة بأنماطها المختلفة شربكا فاعلا ومؤثرا في الطفل وأدبه،

$$
\text { بعد أن أصبح أكثر تفاعلية وانفتاحا ووعيا بعالمه المعاصر • }
$$

Y. كانت المعرفة التقافية تقوم على قراءة النصوص الأدبيـة التقليديـة عبر المطبوعات الثابتة والوسـائط الورقيـة، وبظهور وسـائل الاتصال في الإعـلام والإنترنت وانتقال المعرفة بينها، 
تعددت النصوص الرقمية وأخذت أشكالا متتوعة منها:القصة، والحكايـة، والأغنية وغيرها، ووصـلت للتشويق والإثـارة واسـتطاعت أن تخلـق جـوا مـن التفاعل والعمـل الجمـاعي بـين الأطفال والنصوص الأدبيـة وسـحت لهم بالارنبـاط العضوي بـالمتمع ،كما تفاعلت مـع الطفل وسـاعدته على التخلص من انطوائه والإحساس بالإيجابية حين يشارك بالتدخل في أحداث-القصة-وتغيير المسار الدرامي لها، كذلك أيضا مكنتهه من أن يكون منتجا مبدعا للنصوص، متذوّقا للأدب والفنّ، وناقدا. r. لا توجد وسيلة إعلامية تغني عن الأخرى، فما زالت كتب ومجلات الطفل وغيرها من أنواع المطبوعات موجودة وقادرة على استقطاب جمهور القراء، فالحقيقة العلمية تؤكد أن الإعلام المرئي والمكتوب سيظل لهما دور ووجود في الحياة. ع. لا مكان لما يُقدم من برامج إعلامية للطفل تتخذ مسارا وعظيا عنيفا،حتى لا يفتقدالطفل المتعة والسعادة التي ينمو من خلالهما لغويـا ومعرفيـا وذوقيا وخيـالا وفكرا،فضلا عن حمايته من

$$
\text { الصدمات الإنفعالية والوجدانية. }
$$

هـ معظم الأطفال في الوقت الحاضر يفضلون الإعلام الفضائي؛ لما يبثه من حكايات ومشاهد بصرية وخيال ممتع فهو ملاذهم الذي يلجئون إليه لإيجاد المتعة والتسلية والتنيقف. 7. الكتابـة للأطفال ليست بـالأمر اليسير ، ولا بـ من إدراك واع لطبيعة الطفل ومراحله العمربـة المختلفة وحاجاته العقلية والنفسية، بالإضافة إلى الموهبة، لامتلاك زمام الوصول إلى وجدانهـ ولبه.

V.تعددت مهارات اتصال أدب الطفل بتعدد نمو تفكير الطفل، والتطورات الصناعية السربعة والتكنولوجية التي أدت إلى ابتكار طرق جديدة مُحسَّنة لتقديم النصوص ؛لذلك يجب توجيه كافة

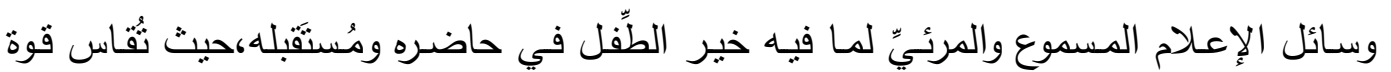
الأمم وحضارتها بمدى اهتمامها الخاص بدراسة الأطفال وثقافتهم وأدبهم وعلومهر، خاصة في 
ظل التطورات الهائلة التي يتسم بها العالم المعاصر - والمتوقعة مستقبليا في كافة مجالات الحياة الإنسانية ، ولذلك نوصي بما بلي:

أ.يجب استغلال وسائل الاتصال الحديثة والاستفادة من إمكاناتها وتطويرها وتحسين أدائها، في إنتاج برامج إعلامية في مجالات متعددة ومنها مجال أدب الطفل، لتحفز آليات تفكير الطفل، وتمكنه من تتمية قدراته اللغوية ، وتغرس فيه والولاء والانتماء الوطني، وتعرفه بجمال بـلاده، وتتمي ملكة الابداع لديه، وتعوده على الفكر المنظم،وتتشط نزعتي التركيب والتحليل، فضلا عن اشباع رغباته وتطلعاته إلى حب الاكتشاف والاختراع، وغرس محبـة العمل في نفسه ومحبة الآخرين • ومن ثم يمكن الخروج عن النموذج التقليدي القائم على النموذج الخطي والحكائي للمعرفة سابقا. ب. إنشاء أدب جديد يقديم عرضا تفصيلا عن مفهوم القصة الرقمية ومميزاتها وعناصرها وطريقة عملها، الاهتمـام بالرسـوم التي يتم إضـافتها في الكتب الخاصـة بالطفل؛لأسـر لبهـ وتحبيبه بالكتاب. ت.منـع القصص والحكايـات والأغـاني التي تقدم نمـاذج سـلبية للطفـل، والاهنمـام بالمواضـيع المستوحاة من بيئنه التي تغرس قيماً إيجابية في نفسه، والتأكيد على أهمية الأغاني والأناشيد التراثية التي يتعرف عليها منذ البدايات الأولى لحياته، مع خلق أغاني وأناشيد جديدة تنتاسب مع عالم الحجرات المغلقة والتلفزيون والكومبيوتر • وكذلك الاهتمام بقصص الخيال العلمي التي

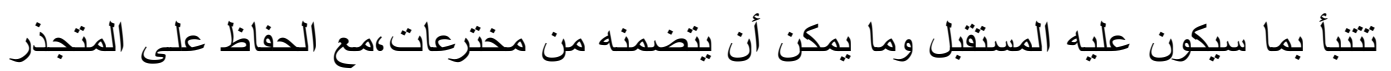
من التراث الأدبي، لترسيخه بين الأطفال وتجسيده (بالصورة الصوت والحركة فيتعايش معه الطفل وكأنه واقع يشاهده أمامه) لربط الحاضر بالماضـي والانطلاق بـه إلى مستقبل أفضل، والاصـرار على استمرار التجريب ومتابعة التنظير ، مما يؤدي إلى تعميق المضمون وإتاحة الفرصة للتعبير عن المعارف. 
ث. تصميم بر امج إعلامية إلكترونية في إطـار إعلامس قائم على استر اجيات وأسس ثابتـة للدم فنون أدب الطفل و أهدافه واستر اتجياته ومناهجـه ،الأمر الذي يساعد الطفل على تقويم لغته التي هي كيانه، وتشكيل عقله وتوجيـه سلوكه، وتزويده بالمعلومات والمهارات والفنون التي تساعده على الإحاطة والتفوق، تكوين شخصية سوية وإكسابه مهارات التفكير السليم ،والفهم لمـا بـدور حولـه ومستاركة غيره دون التفربط في الثوابت والمبـادئ، مـع مراقبـة ومنع الآبـاء لأطفالهم من متابعة المضامين التي لاتتاسبهم وهو ما يعرف"بفلسفة التربية الإعلامية"لحمايهر

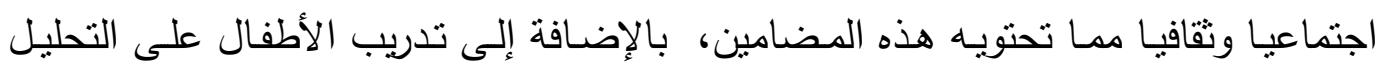
والتقيم والنقد الموضوعي لما يُشاهد أو يقدم، وانتاج برامج نرقى بأذواق أطفالنا وتضع عاداتتا وقيمنا على رأس اهتماماتهم مع مناهضة كل تقكير منحرف يعكر صفو المجتمع ويمزق هويته ويدمر استقراره .

\section{الإهوامث}

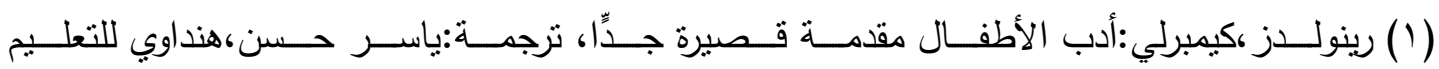

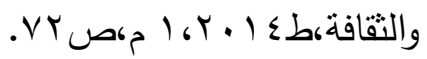

(Y) عبد الحسيب،محمد ثيمور ،علم الدين،محمود:الحاسبات وتكنولوجيا الاتصال،القاهرة،دار الشروق،

$$
\text { . } 1490 \text { (1) } 199 \mathrm{~V}
$$

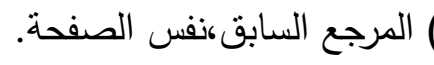

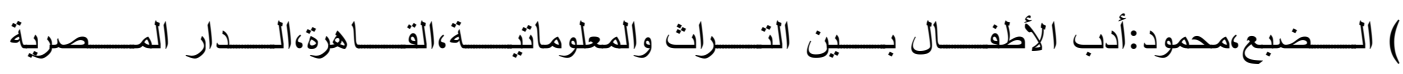

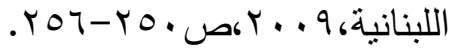

(0) السلطان،عبد العزيز،الفنتوخ،عبد القادر :الإنترنت في التعليمهشروع المدرسة الإكترونيةهرسالة الخليج

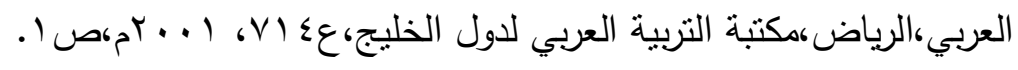

http://alqudslana.com/index.php?action=article\&id=2793: انظر

نفس المصدر (V) 
(^) شبلول،أحمد فضل: تكنولوجيا أدب الأطفال،دار الوفاء لدنيا الطباعة والنشر،الاسكندرية، ط.... ؟،ام،

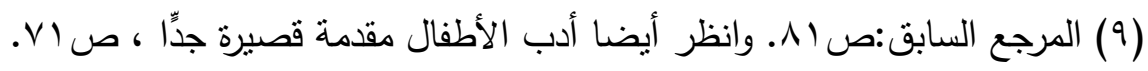

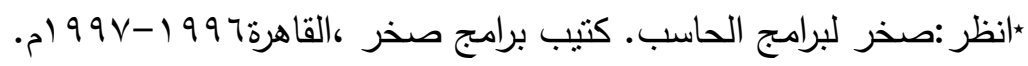

**:انظر : ابن المققع،عبد الله:كليلة ودمنة، تحقيق وتقديم:محمد أمبن فرشوخ، بيروت،دار الفكر العربي،

$$
.1 V R-179 \text { ص ص (199. }
$$

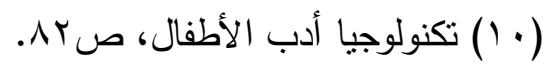

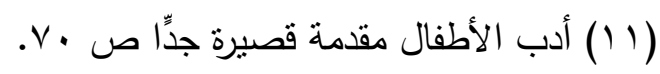

(Y ( ) السيد،سعدعلى:أسس انتاج القصة التفاعليـة في بـرامج الكومبيوتز التلعيميـة وفاعليتها في تعليم

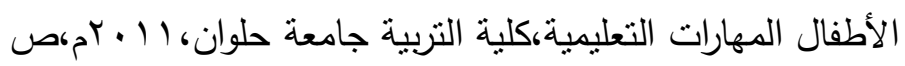

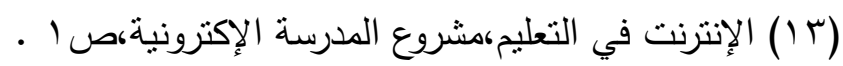

( ) ( انظر :فلاتـة، مصطفى بن محمد عيسي: المـخل إلى التقنيات الحديثة في الاتصال والتعليم،

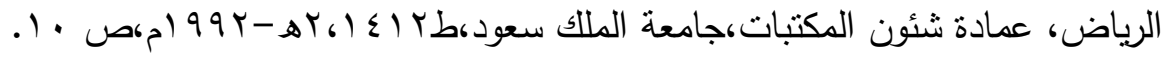

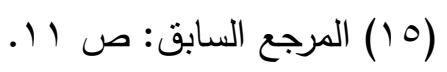

(7 ( ) انظر : الحاسوب للتعلم والتعليم: المجلـة العربيـة للتربيـة، تونس، المنظمـة العربيـة للتربيـة والتقافـة

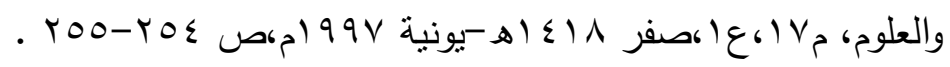

( V) انظر :العياضي، نصر الدين:المادة الثقافية في التلفزيون،صراع التقنية والتزفيه،هجلة الرافد، الثارقة،

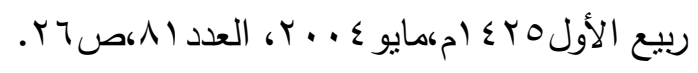

(1 (1) انظرعبد الله، صفا فوزي على:علاقة الطفل المصري بوسائل الاتصال الإكترونية دراسة على عينة

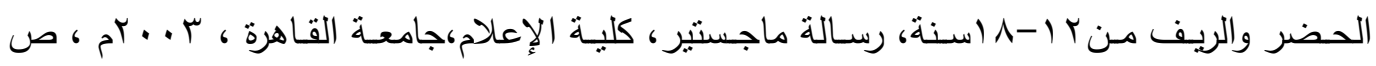

$$
\text { TVO G YVE 6 YTY }
$$

(9 1) سـرج ، أنشرف رشـاد: التفكير الابتكاري لدى الأطفال ومدى تأثره بالألعـاب الإكترونيـة، المكتبـة

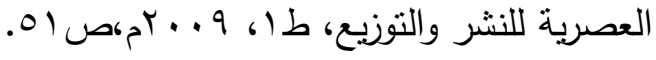

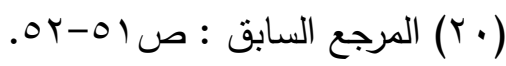




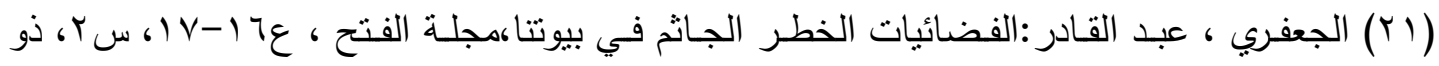

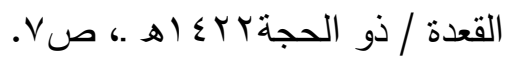

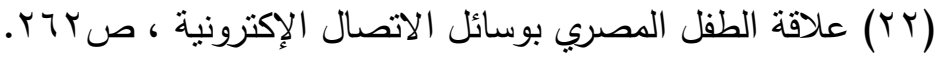

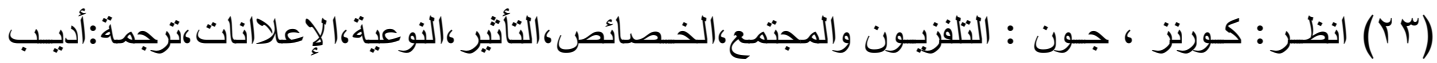

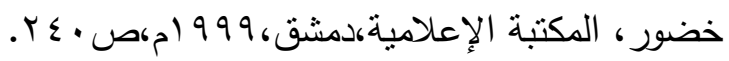

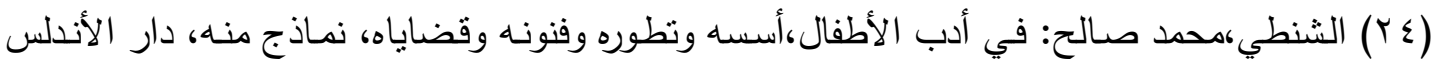

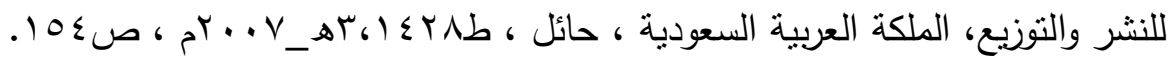

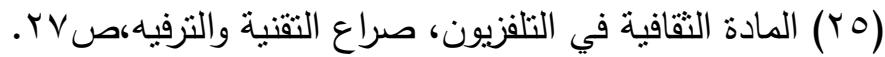

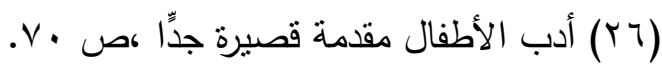

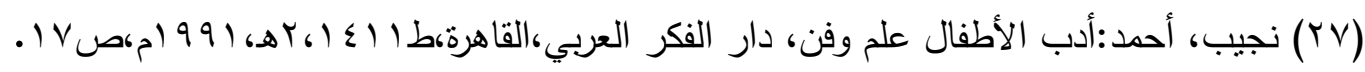

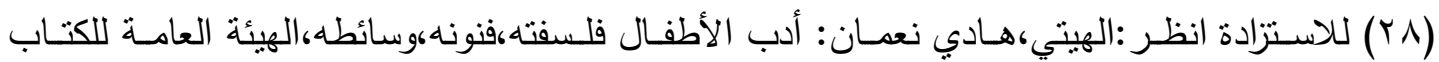

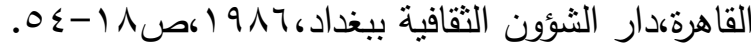

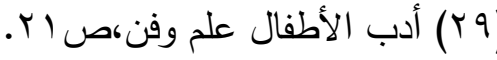

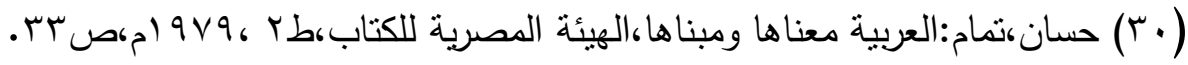

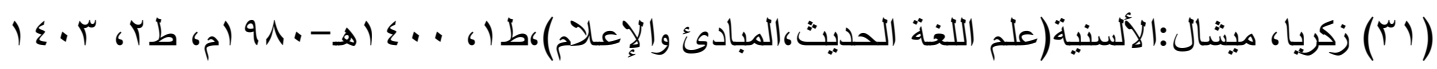

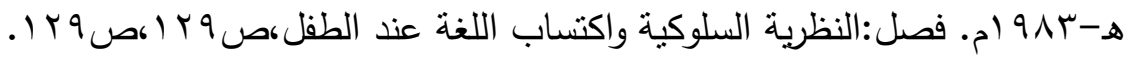

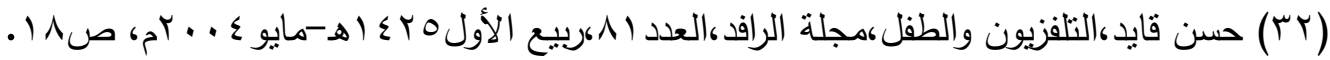

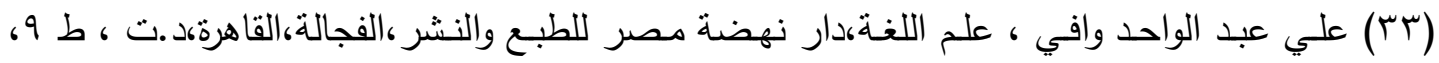
ص. 10.

(ع ب) رمضان ، كافية : التكنولوجيا والثقافة والطفل العربي ، المركز الإقليمي العربي للبحوث والنوثيق في

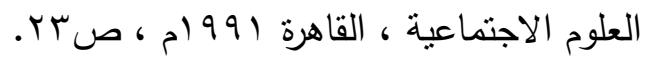

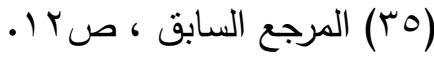

$$
\begin{aligned}
& \text { (דr) في أدب الأطفال: صـ9 } 9 .
\end{aligned}
$$




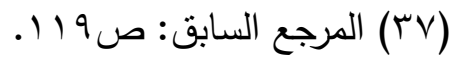

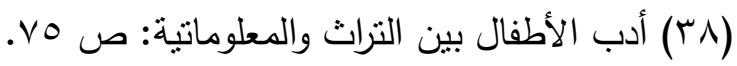

Trillo, Magdalens(2003). The Media the Classrqqm-A Digitl Newspaper, ( $r q$ ) Propsal, Article, Educational Media International, Sep2003m Vol. 40 Issue3/4 p

$$
\begin{aligned}
& \text { ( • ع) الفضائيات الخطر الجاثم في بيوتتا : صل •. }
\end{aligned}
$$

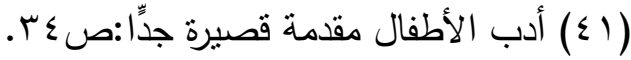

(ץ乏) للاستزادة انظر : يوسف : عبد التواب ، ترجمة كتب الأطفال في الوطن العربي حركتها ومشكلاتها

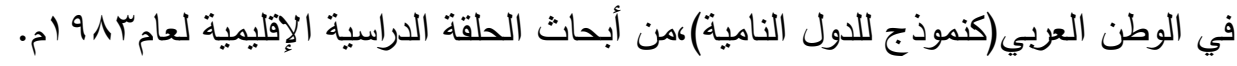

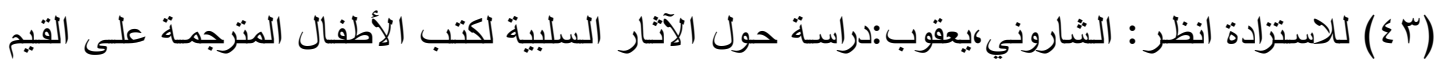

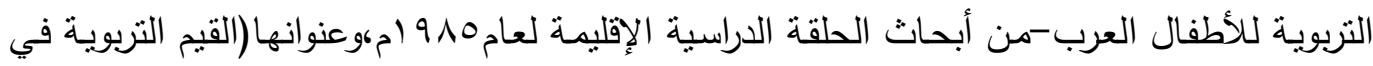
ثقافة الطفل،القاهرة، ب نوفمبر - عديسمبر 910 ام، مركز تتمية الكتاب العربي،الهيئة المصرية العامة

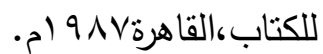

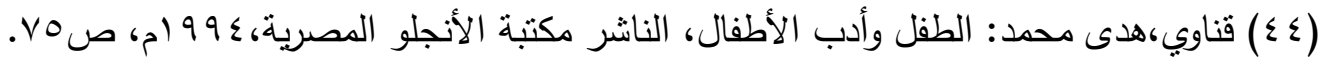

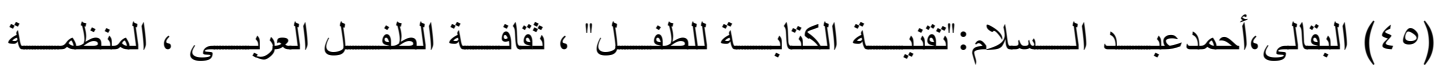

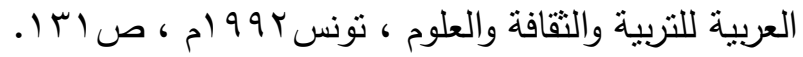

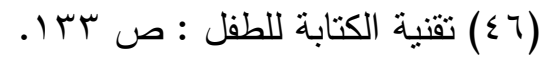

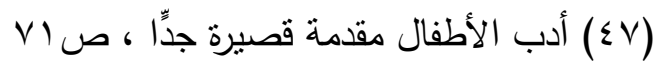

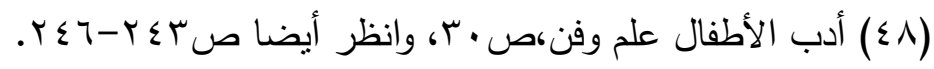
(9 §) سالم،دعاء فتحي:"دراسة مقارنة بين دوافع استخدام المراهقين لمجلات الأطفال الإكترونية والورقية والإشباعات المتحققة من كل منهما"رسالة دكتورا،جامعة عين شمس،معهد الدراسات العليا للطفولة ،

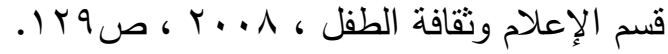
(0) (م) الطفل وأدب الأطفال : صهم ونه. 
Teixeira, Marcelo Mendonca,Silva,Bento (2011)."Digital Radio Broadcast; (0 1) New Technological Resources to produce Educational programs Online".The Journal for Open and Distance Educational T echnology,7 (1).ISSN:1791-

$$
\begin{aligned}
& \text { (Or) أدب الأطفال،فلسفته، فنونه،وسائطه ص ع مr. }
\end{aligned}
$$

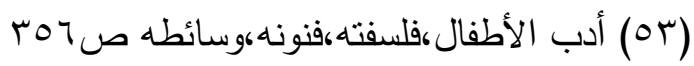

$$
\begin{aligned}
& \text { r ( }
\end{aligned}
$$

(0) رزق الله ، رائف ، التلفزيون والأطفال ، التسرب الأيدلوجي من خلال الصورة ، من كتاب نقافة

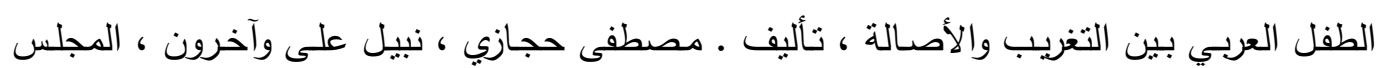

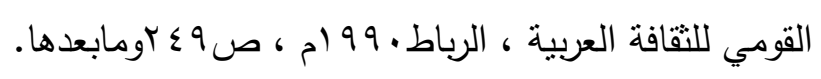

\section{المصادر والمراجع}

- البقالى،أحمدعبدالسلام:"تقنية الكتابة للطفل"،تقافة الطفل العربى،المنظمة العربية للتربية والثقافة والعلوم،

$$
\text { تونس } 999 \text { (م) }
$$

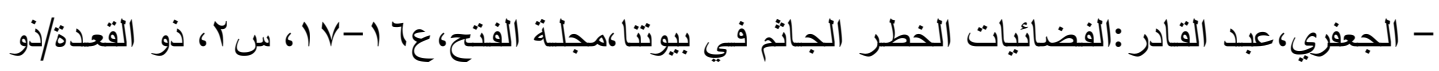

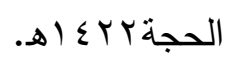

- الحاسـوب للتعلم والتعليم: المجلـة العربيـة للتربيـة، تـونس، المنظمـة العربيـة للتربيـة والتقافـة والعلوم،

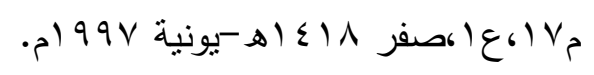

- حجازي، مصطفى-على،نبيل وآخرون :ثقافة الطفل العربي بين التغريب والأصـالة ،المجلس القومي

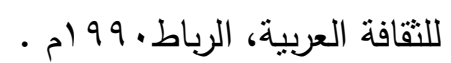

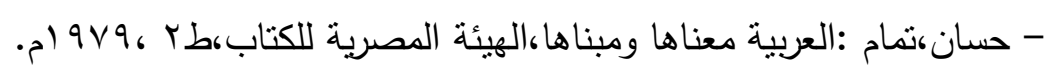

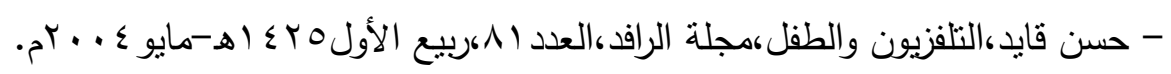

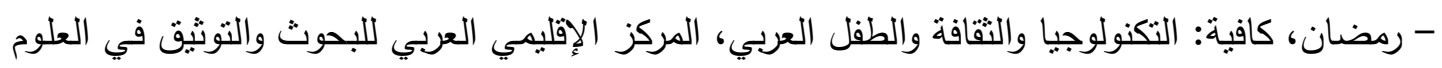

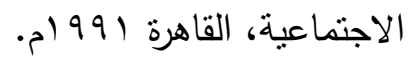

$$
\text { العقد التزاسع / يناير - VI. }
$$


- رينولدز ،كيمبرلي، أدب الأطفـال مقدمـة قصيرة جدًا، ترجمـة : ياسـر حسن،هنداوي للتعليم والثقافـة ،

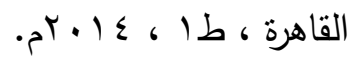

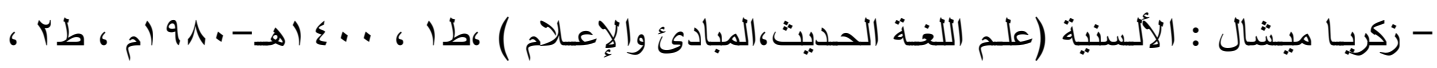
.

- سالم ، دعاء فتحي : "دراسة مقارنة بين دوافع استخدام المراهقين لمجلات الأطفال الإكترونية والورقية والإثباعات المتحققة من كل منهما"رسالة دكتورا،جامعة عين شمس،معهد الدراسات العليا للطفولة،قسم

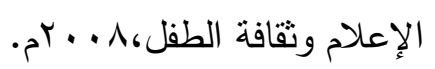
- سرج، أثنرف رشاد: التفكير الابتكاري لدى الأطفال ومدى تأثزه بالألعاب الإككترونية، المكتبة العصرية

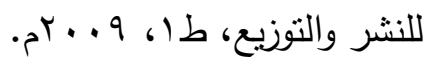

- السلطان،عبد العزيز،الفنتوخ،عبد القادر :الإنترنت في التعليمهشروع المدرسة الإكترونية،رسالة الخليج

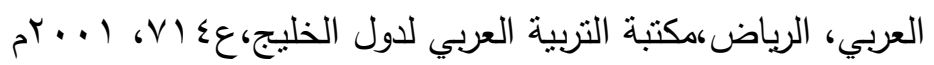
- السيد،سعدعلى:أسس انتاج القصة التفاعلية في برامج الكومبيونز التلعيمية وفاعليتها في تعليم الأطفال

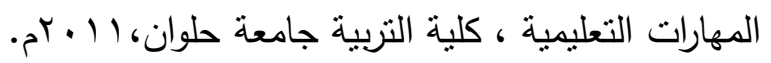

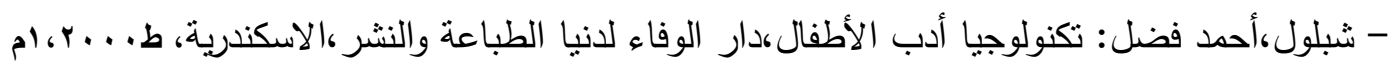
- الشاروني،يعقوب:دراسـة حـول الآثار السلبية لكتب الأطفال المترجمـة على القيم التربويـة للأطفال

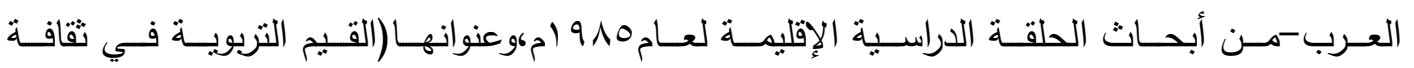

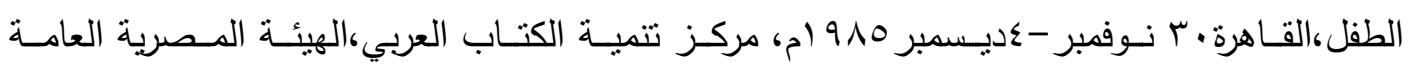

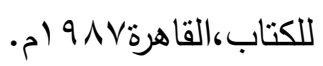
- الشنطي،محمد صالح: في أدب الأطفال،أسسه وتطوره وفنونه وقضاياه، نماذج منه، دار الأندلس للنشر

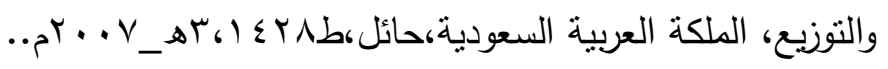

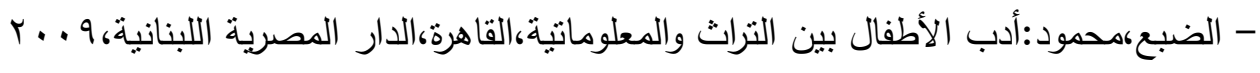

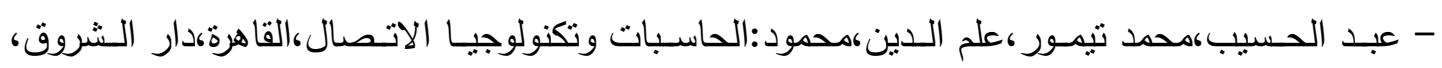
2) $99 V$ 
- عبد الله، صفا فوزي على:علاقة الطفل المصري بوسائل الاتصال الإكترونية دراسة على عينة الحضر

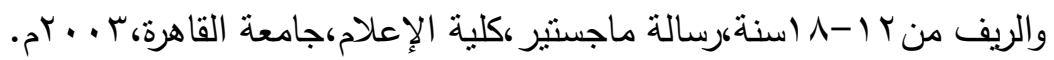
- علي عبد الواحد وافي،علم اللغة،دار نهضة مصر للطبع والنشر ،الفجالة،القاهرة،د.ت ،طو. - العياضي، نصر الدين:المـادة الثقافية في التلفزيون،صراع التقنية والترفيه،مجلة الرافد، الشارقة، ربيع

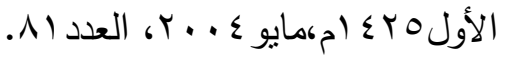

- فلاتة، مصطفى بن محمد عيسي: الددخل إلى التقنيات الحديثة في الاتصال والتعليم، الرياض، عمادة

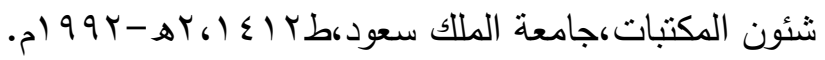

- قناوي،هدى محمد: الطفل وأدب الأطفال، الناشر مكتبة الأنجلو المصرية، 99 ام.

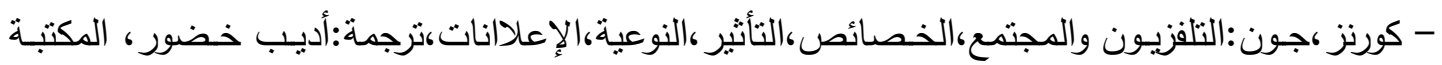

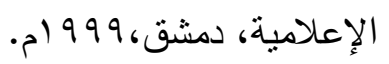

- ابن المقفع،عبد الله:كليلة ودمنة، تحقيق وتقديم:محمد أمين فرشوخ، بيروت،دار الفكر العربي، . 199 .

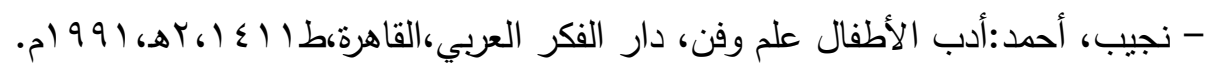
- الهيتي،هادي نعمان:أدب الأطفال فلسفته،فنونه،وسائطه،الهيئة العامة للكتاب القاهرة،دار الثؤون التقافية بيغداد،

- يوســف: عبـد التـواب:ترجمـة كتـب الأطفـال فـي الـوطن العربـي حركتهـا ومسشكلاتها فـي الـوطن

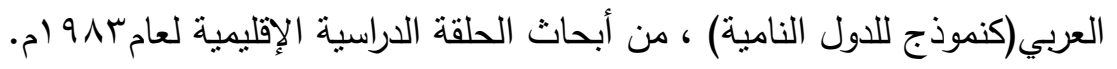

-Trillo, Magdalens(2003). The Media the Classrqqm-A Digitl Newspaper, Propsal, Article, Educational Media International, Sep2003m Vol. 40 Issue3/4 p 269.

-Teixeira, Marcelo Mendonca,Silva,Bento (2011)."Digital Radio Broadcast; New Technological Resources to produce Educational programs Online".The Journal for Open and Distance Educational T echnology,7 (1).ISSN:1791- 9312. -http://alqudslana.com/index.php?action=article\&id=2793 